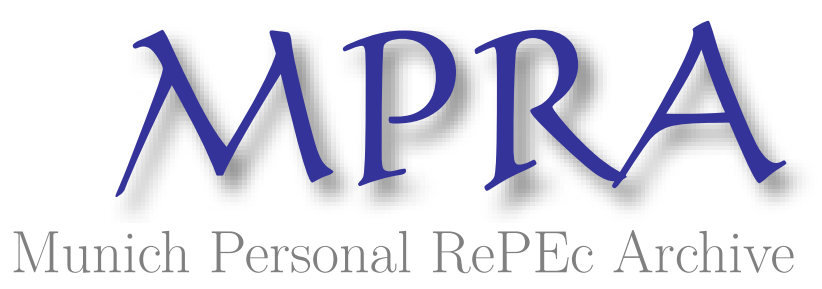

\title{
Adjustment to Negative Price Shocks by a Commodity Exporting Economy: Does Exchange Rate Flexibility Resolve a Balance of Payments Crisis?
}

Nakatani, Ryota

International Monetary Fund

3 June 2018

Online at https://mpra.ub.uni-muenchen.de/87153/

MPRA Paper No. 87153, posted 07 Jun 2018 08:43 UTC 


\title{
Adjustment to Negative Price Shocks by a Commodity Exporting Economy: Does Exchange Rate Flexibility Resolve a Balance of Payments Crisis?
}

\author{
Ryota Nakatani \\ International Monetary Fund \\ 700 19th Street, NW, Washington, D.C. 20431 U.S.A. \\ Email: nakatani.ryouta@gmail.com
}

May 2018

\begin{abstract}
Negative commodity price shocks can induce balance of payments crises in resource dependent economies. Governments often react by intervening against currency depreciation as, for example, in the case of Papua New Guinea in response to the commodity price shocks of 2014. We develop an original theoretical model to analyze the balance of payments impact of a commodity price shock under alternative exchange rate regimes: a flexible rate regime and a fixed rate regime with foreign exchange rationing. The balance of payments consequences are shown to depend on the elasticity of exports and imports with respect to the exchange rate. For the Papua New Guinea case, we estimate export elasticities for a variety of commodities (gold, silver, copper, oil, coffee, cocoa, copra, copra oil, palm oil, rubber, tea, logs, and marine products) as well as for imports. The results indicate that the Marshall-Lerner condition is satisfied for this resource-rich economy, implying that exchange rate flexibility may be practicable. We implement our calibrated model to conduct a counter-factual simulation and find that with a flexible exchange rate, foreign reserves would have been 20 percent higher three years after the shock than they were under the actual policy of exchange rate stabilization. In light of this, we argue the merits of greater exchange rate flexibility.
\end{abstract}

JEL Classification Numbers: F31, F32, F41, O13, Q17, Q37

Keywords: Commodity Exporters, Foreign Exchange Rationing, Papua New Guinea, MarshallLerner Condition, Agriculture, Mining. 


\section{INTRODUCTION}

The sharp decline in oil prices beginning in mid-2014 had a major impact on commodity exporting countries. Low commodity prices have created numerous challenges in resource-rich economies, particularly low-income ones. These include lower export revenues, shortages of foreign reserves, and weakened fiscal positions. Figure 1 compares foreign reserve holdings in the post-2014 period of commodity exporting countries with non-commodity exporting countries. The commodity exporting countries experienced an average decrease in reserves of more than 20 percent by 2017 due to lower export revenues, while by contrast non-commodity exporting countries accumulated reserves. Another common experience of commodity exporting countries in the wake of the price shock was import compression owing to a shortage of foreign exchange ( $F X)$ earnings. As shown in Figure 2, imports of commodity exporting countries contracted by roughly 25 percent on average, with no sign of rebound by mid-2017. By contrast, imports in non-commodity exporting countries had by this time recovered to their pre-shock level. The drop in export revenues and compression of imports of commodity exporters undermined overall economic performance leading to a deterioration in fiscal positions, as evidenced in Figure 3. From a balanced budget on average in 2013, commodity exporters saw fiscal deficits widen to 9 percent of gross domestic product in 2015 and 2016, while the budget balance remained stable for non-commodity exporters.

Figure 1. Foreign Reserves for Commodity and Non-Commodity Exporters, 2014-2017

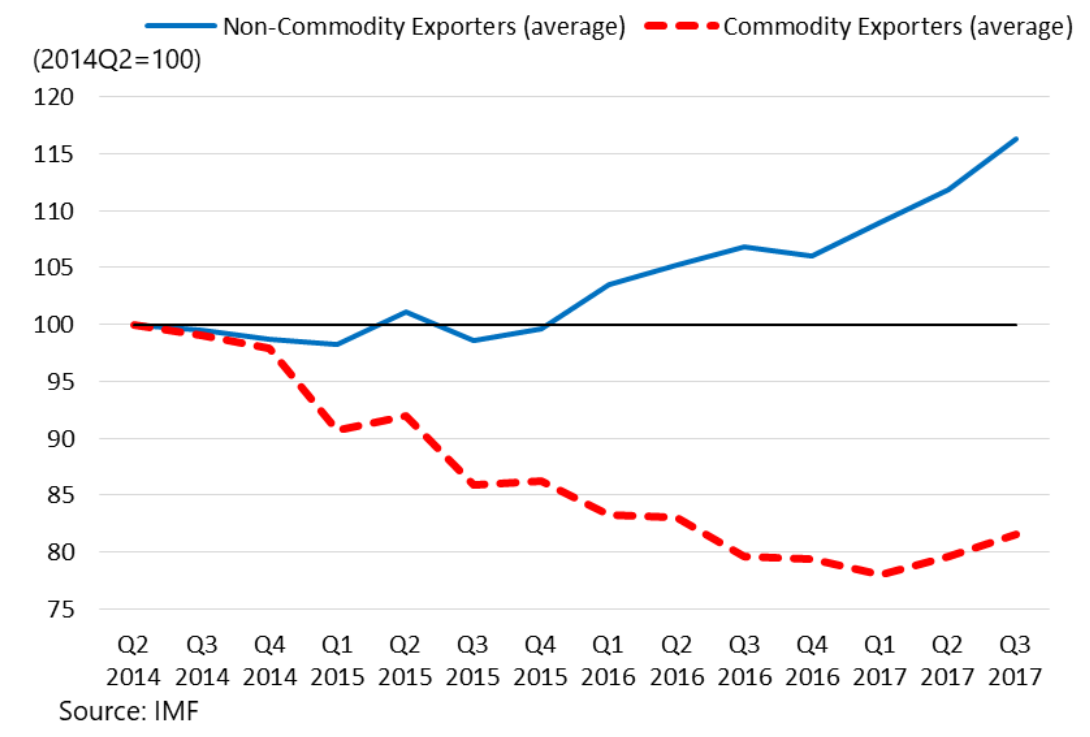

Note: Countries included in Figures 1-3 comprise of 44 commodity exporting and 129 non-commodity exporting countries listed in Appendix A. Commodity exporters are countries included in the IMF's World Commodity Exporters Database. 
Figure 2. Imports for Commodity and Non-Commodity Exporters, 2014-2017

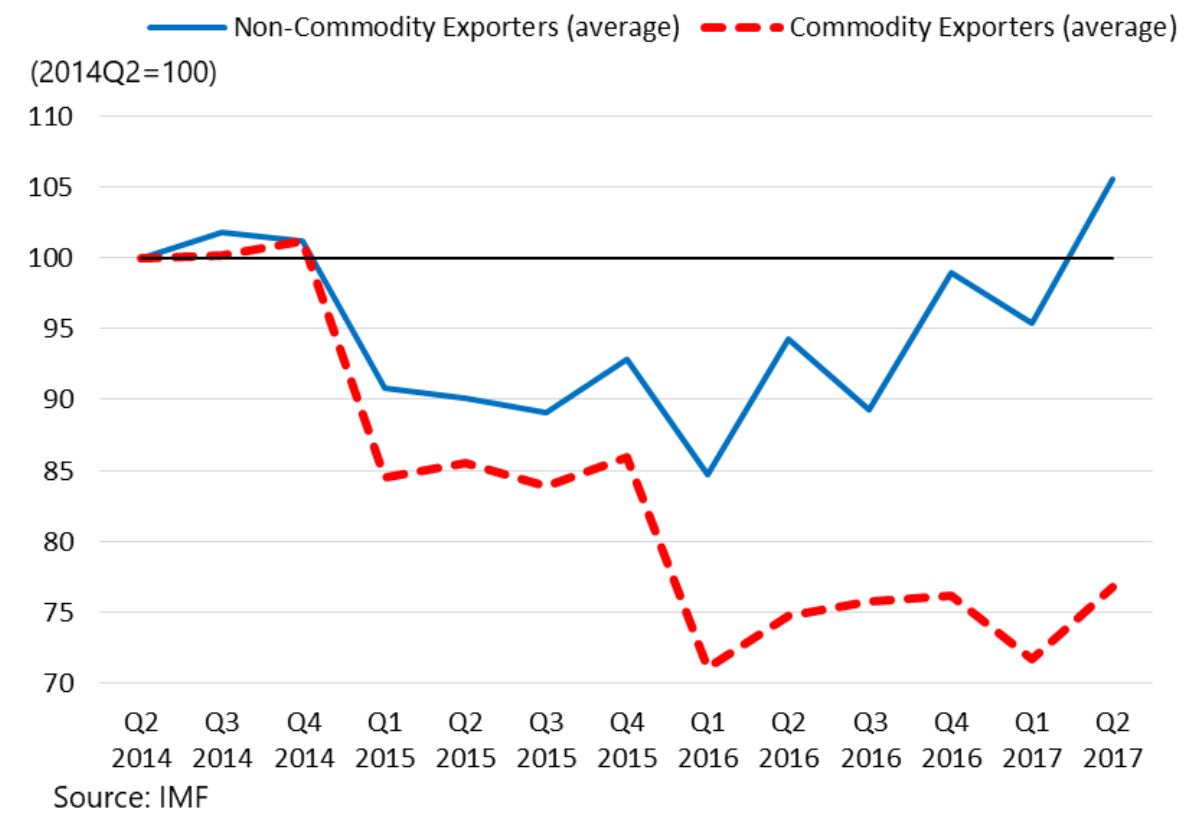

Figure 3. Budget Balance for Commodity and Non-Commodity Exporters, 2013-2016

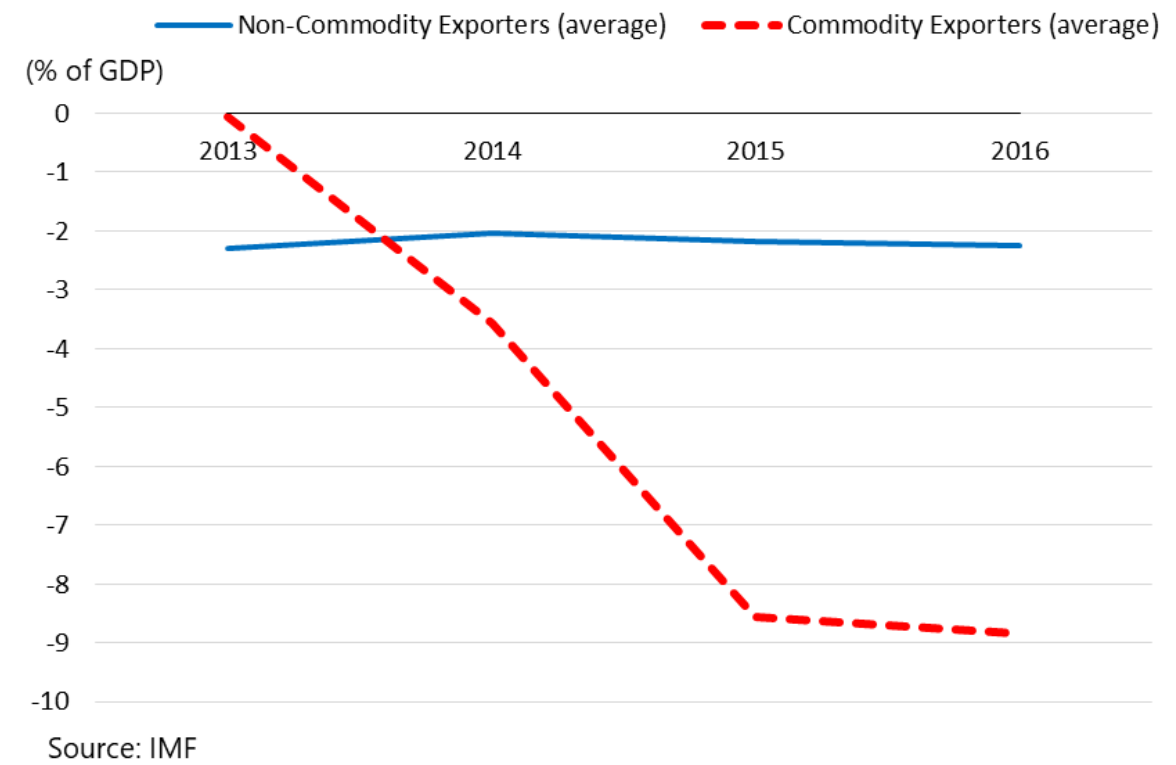

Motivated by these stylized facts, we analyze the external adjustment in a resource-rich economy following negative commodity price shocks. We develop a theoretical model and implement it for the case of Papua New Guinea (PNG), then draw implications for exchange rate policy with an eye to interactions with fiscal and monetary policies.

We construct an original model to compare two exchange rate regimes - a fixed exchange rate regime with $\mathrm{FX}$ rationing and a flexible exchange rate regime - with regard to their performance 
following a negative terms-of-trade shock. Adjustment following terms-of-trade shocks has been studied in the macroeconomic literature broadly. Open-economy macro models indicate that a flexible exchange rate policy can be effective in handling the terms-of-trade shock because the nominal exchange rate adjusts immediately to the shock. If the Marshall-Lerner condition is satisfied, a depreciation of the home currency affects the trade balance positively. Empirical studies have found that this condition holds in many advanced economies. However, it is unclear whether the condition holds in a small resource-rich economy because most commodity export prices are denominated in U.S. dollars and determined in world markets, and many such countries rely on imports to meet a large fraction of domestic demand for intermediate and final goods due to under-developed domestic production capacity. These circumstances imply low price elasticities for both exports and imports. For our case study of resource exporter PNG, we estimate elasticities of various commodity exports with respect to the exchange rate.

PNG is the largest developing economy among Pacific island nations and one of the most resource-rich countries in the world with exports of metals, oil and gas, and commodities from agriculture, forestry, and fishery sectors. The country ranks within the world's top 10 for exports of liquefied natural gas (LNG) and tropical logs, and in the top 20 for production of coconut, palm oil, cocoa, gold, and coffee (Nakatani 2017a). Further, the country is located next to the world's largest sustainable tuna purse seine fishery and draws 30 percent of the total fish net catch among the Parties to the Nauru Agreement. In sum, PNG has abundant natural resources for export. Its experience with a very diverse set of commodity exports offers a rich context for analyzing export price elasticities. Thus the policy implications generated in this paper should be useful not only for PNG but for other resource-rich economies as well. Our model applies generally to an economy that produces and exports natural resources and agricultural products while importing manufactured goods for consumption. In this situation, negative export price shocks cause adjustment on the import side as a result of FX rationing (see, for example, Adler, Magud and Werner, 2018). 
Figure 4. Energy Prices, Exchange Rates, and Foreign Reserves in Papua New Guinea, 20142017

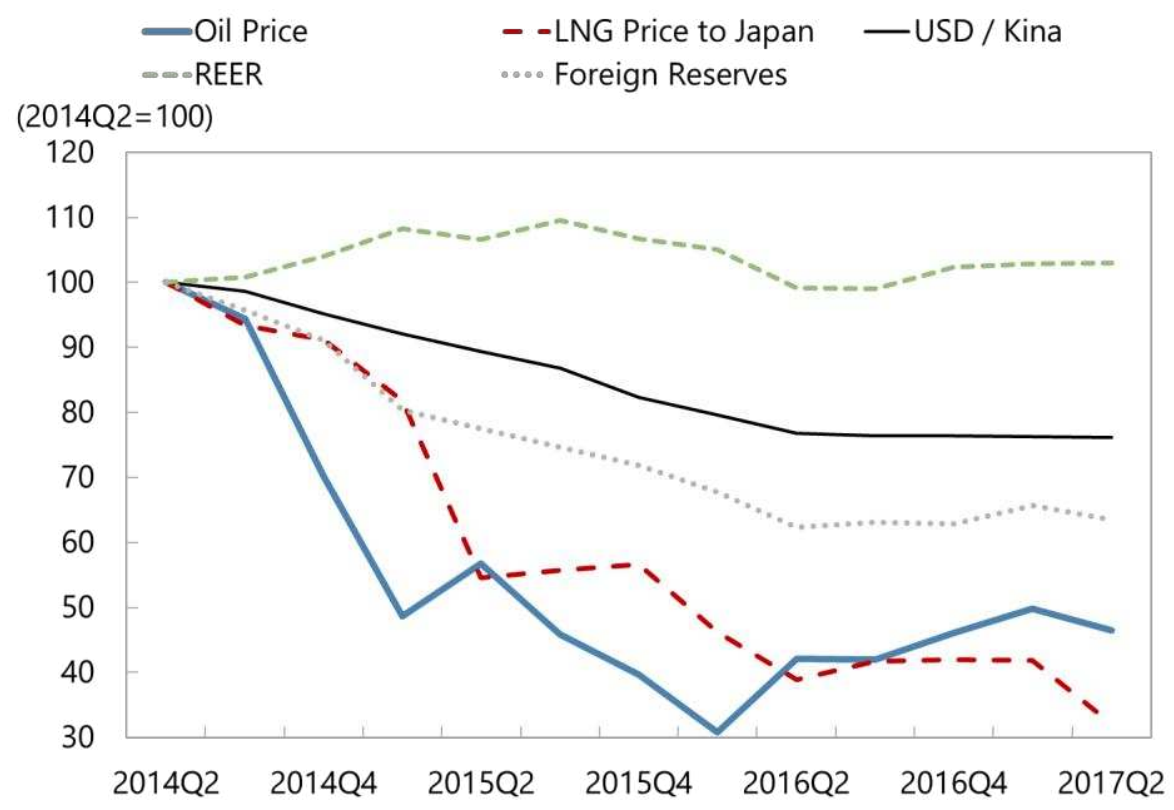

Source: IMF

PNG is a commodity exporter facing the challenge of external adjustment in an era of low commodity prices. As shown in Figure 4, from 2014 Q2, oil and gas prices declined drastically by about 60 percent. Falling exports, coupled with a suspension of production in the mining and agricultural sectors due to a major drought, ${ }^{1}$ contributed to nominal exchange rate depreciation of the PNG kina relative to the U.S. dollar by 24 percent between June 2014 and May 2016. The Bank of Papua New Guinea (BPNG) intervened in the FX market to support the kina, resulting in a depletion in foreign reserves. Meanwhile, the real effective exchange rate (REER) was held broadly stable. After May 2016, the U.S. dollar exchange rate also stabilized, and foreign reserves, too, held steady as the BPNG refrained from intervening in the FX market once mining resumed. A salient feature of the PNG experience was that the de facto exchange rate regime changed from floating to fixed with FX rationing. As a result of FX rationing, imports in the non-resource sector contracted by about $\$ 950$ million relative to trend due to a lack of access to FX, as shown in Figure 5. The policy decision to control the exchange rate and ration FX was motivated by concerns about the inflationary impact of currency depreciation and the limited responsiveness of net exports to the exchange rate. A theoretical as well as an empirical approach are deployed to evaluate this exchange rate policy transformation.

\footnotetext{
${ }^{1}$ The drought brought by El Niño caused water levels to drop, which affected shipping operations and resulted in a nine month shut down of Ok Tedi Mine commencing in July 2015.
} 
Figure 5. Ratio of Non-Resource Imports to Non-Resource GDP in Papua New Guinea, 20062017

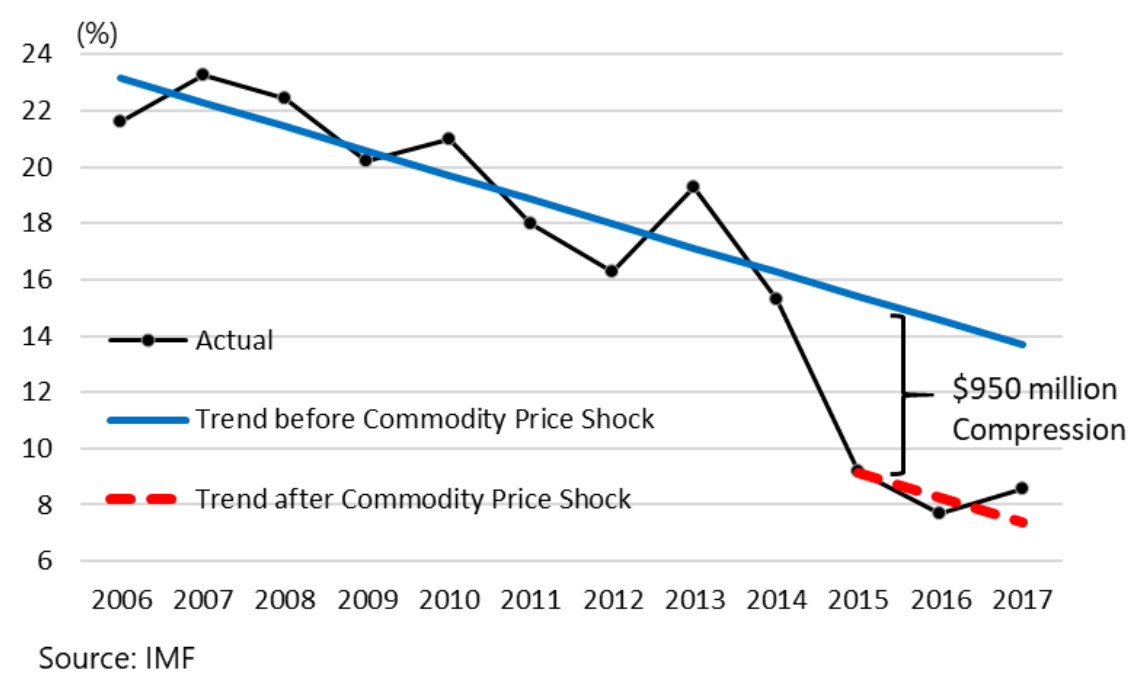

This paper offers two contributions: an original theoretical model of exchange rate policy alternatives in the context of a balance of payments (BOP) crisis induced by commodity price shocks; and an empirical estimation of PNG's export and import elasticities with respect to the real exchange rate for implementation of the model. Most theoretical papers on BOP crises have focused on inconsistent macroeconomic policy mixes, self-fulfilling prophecies, and financial frictions leading to problems of maintaining a fixed exchange rate regime with finite foreign reserves. These studies have not explicitly investigated the role of commodity price shocks leading to BOP crises. At the same time, few papers have explicitly analyzed FX rationing as a policy response to a BOP crisis, although a few studies have analyzed the theoretical implications of shifting from a flexible to a fixed rate regime under BOP pressures (see van Wijnbergen, 1991). In this paper, we extend the Nakatani (2016) model by incorporating agricultural and mining sectors, and compare the consequences of a fixed exchange rate regime with FX rationing versus a flexible exchange rate regime. Further, using commodity export data, we estimate elasticities of various commodities with respect to real exchange rates based on both panel regression techniques and cointegration estimation for each export commodity.

Do commodity exports respond to exchange rates? Yes. Our empirical results of both panel and individual commodity regressions indicate that the overall elasticity of exports with respect to the real exchange rate is around -0.4 . The theoretical model shows that a shortage of foreign reserves leads to import compression and reduces consumer welfare. It further shows that depreciation of the domestic currency can be a policy tool to mitigate a BOP problem if trade is elastic with respect to exchange rates. Using the trade elasticities estimated in the empirical exercise, we conduct counter-factual calibration to measure the effects of currency depreciation on foreign reserves via increased commodity exports and reduced imports.

The remainder of the paper is organized as follows. Section 2 provides a literature review and explains key contributions of this paper in the context of the theoretical and empirical literature. Section 3 builds a theoretical model to analyze the effects of a commodity price shock on the BOP and derives policy implications. Section 4 estimates the effects of real exchange rate 
adjustments on exports and imports using PNG's trade volume data. Section 5 simulates the effects of currency depreciation on FX for PNG. Section 6 discusses policy implications and Section 7 concludes.

\section{Literature ReView ANd OUR CONTRIBUtions}

The adjustment to terms-of-trade shocks has been widely studied in the open-economy macroeconomics literature. A typical open-economy macro model suggests that economies with more flexible exchange rate regimes exhibit smaller output responses during commodity price boom and bust episodes (Céspedes and Velasco 2012). A flexible exchange rate helps stabilize the economy in response to terms-of-trade shocks because the nominal exchange rate adjusts immediately to the real shock in the presence of other nominal rigidities. Empirically, countries with fixed exchange rate regimes have been found to experience large and significant declines in real GDP in response to negative terms-of-trade shocks because the real exchange rate depreciates slowly (Broda 2004; Edwards and Levy Yeyati 2005). Recent observations for commodity exporting countries in Latin America show that real exchange rate depreciation has led to an increase in exports and a stronger reduction in imports in connection with expenditure switching from foreign goods to domestic goods (IMF 2017a). However, terms-of-trade shocks have not been analyzed in the context of BOP crises. $^{2}$

An adverse commodity-price related terms-of-trade shock can challenge the viability of a (de facto) fixed exchange rate regime, although the literature has not focused on such shocks. The first-generation models of BOP crises were developed by Krugman (1979). In these models, a BOP crisis is caused by an inconsistent fiscal and monetary policy mix under the fixed exchange rate regime. The second-generation model was developed by Obstfeld (1996), who analyzed the self-fulfilling prophecy caused by the interaction of international investors and the monetary authority. The third-generation models focus on various financial frictions and banking problems, including debt denominated in foreign currency of firms (Nakatani 2014) and of banks (Nakatani 2016), liquidity problems due to collateral constraints (Caballero and Krishnamurthy 2001), traditional bank runs triggered by stochastic patience of depositors (Chang and Velasco 2001), and moral hazard problems caused by explicit or implicit government guarantees (McKinnon and Pill 1999; Burnside, Eichenbaum and Rebelo 2004). We develop a fourthgeneration model that highlights commodity-price shocks in inducing BOP crises.

We compare the costs and benefits of fixed and flexible exchange rate regimes in response to a negative commodity price shock. We introduce agricultural and mining sectors into a simple two-period model originally developed by Nakatani (2016) in a general equilibrium setting for this purpose. The analysis highlights that the costs and benefits of currency depreciation depend importantly on the elasticity of each component of the BOP with respect to the exchange rate. If net trade, especially on the export side, is elastic to exchange rates, the model shows that a depreciation of the domestic currency can improve a country's external position and offer a superior response in terms of consumer welfare. To apply this model, we estimate the elasticity

\footnotetext{
${ }^{2}$ Nakatani (2018a) showed that productivity shocks and risk premium shocks can trigger BOP crises, and Nakatani $(2018 b c)$ estimated the effects of these shocks on output.
} 
of exports with respect to exchange rates using annual commodity export data of PNG. We also estimate import elasticity to check the satisfaction of the Marshall-Lerner condition. The model further shows that if alternatively a fixed exchange rate policy is chosen, authorities have no room to avoid FX rationing in response to the shock, which creates a shadow exchange rate premium to be faced by consumers. Although this paper focuses on exchange rate policy response during the period of commodity price shock and does not examine the period after the policy response, it is worth noting here that if the budget deficit caused by a commodity price shock is financed by the monetary authority, the situation resembles the first-generation models of BOP crises.

The empirical contribution of this paper involves estimation of elasticities of export volumes with respect to exchange rates based on PNG data and related simulation. The empirical literature has reported export elasticities with respect to real exchange rates that range from -0.7 to 0 depending on the nature of the export goods. For instance, the External Balance Assessment (EBA)-lite, which the IMF (2016) developed, uses an export volume elasticity of -0.71 (and an import volume elasticity of 0.92). For oil-exporting countries, the price elasticity is much smaller, close to zero, because oil exports are priced in U.S. dollars (Behar and Fouejieu 2016). Using cointegration methods without including an exchange rate variable, Aba, Aipi and Irau (2012abc) studied the price elasticity of coffee, cocoa, and palm oil exports in PNG, and found that results are not statistically significant. They stated, however, that the survey conducted by the BPNG showed that all producers interviewed had confirmed that exchange rate fluctuations affect the kina price they receive and a decline in commodity prices serves as a major disincentive for producers. This is because under a currency appreciation, the domestic producer price of a commodity becomes more expensive relative to foreign competitors, and the profits decrease in domestic currency, and vice versa. In our own discussions with the PNG Department of Agriculture and Livestock, officials corroborated that a higher producer price in domestic currency provides important incentives to crop producers and that the exchange rate plays a major role in determining the domestic prices received by producers. In fact, Nkang, Abang, Akpan and Offem (2006) found that the short-run elasticity of cocoa exports in Nigeria with respect to the real producer price is -0.5 . Thus, statistically significant elasticities of those agricultural exports would appear plausible for PNG as well. However, no empirical study has estimated export volume elasticity with respect to exchange rates using PNG data. So this paper estimates PNG's exchange rate elasticities and uses the results to apply our theoretical model for counter-factual policy simulation.

\section{Theoretical AnAlysis}

In this section, we develop a theoretical model to derive implications for exchange rate policy in a resource-rich economy. The model is designed to study the mechanism through which the commodity price shock leads to a BOP crisis, and to yield policy implications for managing external adjustment. Specifically, we compare two exchange rate policies - an FX intervention policy versus a flexible exchange rate policy - to handle the external adjustment required after a permanent negative commodity price shock occurs. 


\subsection{Model}

The model involves two-periods with three agents: firms, households, and a government that operates a central bank. There are two types of firms, agricultural and mining, both of which are owned by the government and foreign investors. The timing of events is summarized as follows. Initial prices are given prior to the shock, based on which all agents have chosen their actions. Then, in the first period an unanticipated negative commodity price shock occurs creating a shortage of FX by reducing export revenues. Concurrently, only the government can respond by choosing either to sell foreign reserves into the FX market or to allow flexibility in the exchange rate, so as to satisfy all equilibrium conditions for the first period. In the second period, the other two types of agents, households and firms, then choose their actions in response to the government policy adopted in the first period.

\subsubsection{Firms}

\subsubsection{Agricultural Firms}

Agricultural firms sell their products to both foreign and domestic consumers, and maximize their profits net of wage payments to employees:

$$
\Pi_{t}^{a}=(1-\tau) P_{t}^{a, f} E_{t} Y_{t}^{a, f}+P_{t}^{a, d} Y_{t}^{a, d}-W_{t}^{a} L_{t}^{a}
$$

where $Y_{t}^{a, f}$ and $Y_{t}^{a, d}$ are the amounts of agricultural goods sold to foreign consumers and to domestic households respectively; $L_{t}^{a}$ is the number of employees in the agricultural sector; $\tau$ is the tax rate; $P_{t}^{a, f}$ is the price of agricultural export goods in foreign currency; $P_{t}^{a, d}$ is the price of agricultural domestic goods in domestic currency; $E_{t}$ is the nominal exchange rate (the price of foreign currency in terms of domestic currency); and $W_{t}^{a}$ is the nominal wage in the agricultural sector. Agricultural firms satisfy the following production function:

$$
Y_{t}^{a}=A_{t}^{a} L_{t}^{a}
$$

where $A_{t}^{a}$ is total factor productivity; and $Y_{t}^{a}$ is the total output of agricultural firms sold on foreign and domestic markets:

$$
Y_{t}^{a}=Y_{t}^{a, f}+Y_{t}^{a, d}
$$

Agricultural export goods are subject to the following demand function defined on the real exchange rate $\left(R_{t}=E_{t} P_{t}^{F} / P_{t}\right)$ and foreign income:

$$
Y_{t}^{a, f}=Y_{t}^{a, f, D}\left(R_{t}, Y_{t}^{F}\right)
$$

where $P_{t}^{\mathrm{F}}$ is the price in foreign countries; $P_{t}=\vartheta^{a} P_{t}^{a, d}+\vartheta^{m} P_{t}^{m} E_{t}+\vartheta^{i} P_{t}^{i} E_{t}$ is a domestic price index, in which each goods is multiplied by its share in the consumption basket characterized later by household behavior; and $Y_{t}^{F}$ is income in foreign countries. The first order condition of the optimization problem of agricultural firms yields:

$$
A_{t}^{a}=W_{t}^{a} / P_{t}^{a, d}
$$


which implies that employment in the agricultural sector is determined at the level where the marginal product in terms of agricultural goods equals the real wage. Agricultural firms pay dividends to both the government and foreign investors as elaborated later.

\subsubsection{Mining Firms}

Mining firms have a similar profit function. Variables are given analogously to the agricultural firms with the superscript $m$ denoting mining, with the following differences. First, the price of mining goods, $P_{t}^{m}$ is determined in foreign currency (e.g., oil or LNG price is in U.S. dollars) and is the same for both domestic and foreign consumers. Second, the government can tax both export goods and domestically sold mining goods. Third, mining firms invest, $I_{t}$, in physical capital, $K_{t}$, each period and make interest payments at a rate, $i_{t}$, in the following period. Fourth, mining firms issue foreign currency denominated bonds, $B_{t}$, on which foreign investors earn interest at rate, $i^{*}$, assumed constant over time. Thus, mining firms maximize profits given as:

$$
\Pi_{t}^{m}=(1-\tau) P_{t}^{m} E_{t}\left(Y_{t}^{m, f}+Y_{t}^{m, d}\right)-W_{t}^{m} L_{t}^{m}-I_{t}-i_{t-1} K_{t-1}-\left(1+i^{*}\right) E_{t} B_{t-1}+E_{t} B_{t}
$$

subject to the Cobb-Douglas production function:

$$
Y_{t}^{m}=A_{t}^{m}\left(K_{t}\right)^{\propto}\left(L_{t}^{m}\right)^{1-\propto},
$$

where $Y_{t}^{m}$ is the total output of mining firms sold on both foreign and domestic markets:

$$
Y_{t}^{m}=Y_{t}^{m, f}+Y_{t}^{m, d}
$$

The equation of motion for capital can be written as:

$$
I_{t}=K_{t}-(1-\delta) K_{t-1}
$$

where $\delta$ is the depreciation rate. The foreign demand for mining goods is characterized by a similar function to that for agricultural goods:

$$
Y_{t}^{m, f}=Y_{t}^{m, f, D}\left(R_{t}, Y_{t}^{F}\right) .
$$

The first order conditions of mining firms hold that the marginal product of labor equals the real wage rate (in domestic currency) in the mining sector:

$$
(1-\propto) A_{t}^{m}\left(K_{t} / L_{t}^{m}\right)^{\propto}=W_{t}^{m} /\left\{(1-\tau) P_{t}^{m} E_{t}\right\}_{1}
$$

and the marginal product of capital equals the real interest rate plus the depreciation rate:

$$
\propto A_{t}^{m}\left(L_{t}^{m} / K_{t}\right)^{1-\propto}=\left(i_{t}+\delta\right) /\left\{(1-\tau) P_{t}^{m} E_{t}\right\}
$$

\subsubsection{Households}

Households maximize the utility function $U\left(L_{t}^{a}, L_{t}^{m}, Y_{t}^{a, d}, Y_{t}^{m, d}, Y_{t}^{i}\right)$, where $U_{L_{t}^{a}}<0, U_{L_{t}^{m}}<0$, $U_{Y_{t}^{a, d}}>0, U_{Y_{t}^{m, d}}>0$, and $U_{Y_{t}^{i}}>0$, subject to the following budget constraint:

$$
P_{t}^{a, d} Y_{t}^{a, d}+P_{t}^{m} E_{t} Y_{t}^{m, d}+P_{t}^{i} E_{t} Y_{t}^{i}+I_{t} \leq W_{t}^{a} L_{t}^{a}+W_{t}^{m} L_{t}^{m}+i_{t-1} K_{t-1}+G_{t}
$$


where $Y_{t}^{i}$ is the amount of the imported consumer good; $P_{t}^{i}$ is its import price in foreign currency; and $G_{t}$ is a government lump-sum transfer to households. The first order conditions of the household's problem yield the following equations that contain the Euler equation:

$$
\begin{gathered}
U_{Y_{t}^{a, d}} / U_{Y_{t}^{i}}=P_{t}^{a, d} /\left(P_{t}^{i} E_{t}\right), \\
U_{Y_{t}^{m, d}} / U_{Y_{t}^{i}}=P_{t}^{m} / P_{t}^{i}, \\
U_{L_{t}^{a}} / U_{Y_{t}^{a, d}}=-W_{t}^{a} / P_{t}^{a, d}, \\
U_{L_{t}^{m}} / U_{Y_{t}^{m, d}}=-W_{t}^{m} /\left(P_{t}^{m} E_{t}\right), \\
\beta U_{Y_{t+1}^{a, d}}\left(1+i_{t}-\delta\right) P_{t}^{a, d} /\left(U_{Y_{t}^{a, d}} P_{t+1}^{a, d}\right)=1,
\end{gathered}
$$

where $\beta$ is the discount factor.

\subsubsection{Government}

The government satisfies the budget constraint and non-negativity constraint of foreign reserves. The government budget redistributes revenues yielded by the country's mining and agricultural resources to citizens. The budget constraint sets tax revenues plus dividends from state ownership ( $\alpha^{a}$ is the fraction of dividends of agricultural firms paid to foreign investors with $1-\alpha^{a}$ the fraction paid to the government; the same notation $\alpha^{m}$ applies to mining firms) equal to transfers to households. There is a one period lag for the payments of taxes and dividends since corporate taxes are based on profits in the previous year. Thus, commodity price shocks affect government revenue in period 2:

$$
\tau\left(P_{t-1}^{a, f} E_{t-1} Y_{t-1}^{a, f}+P_{t-1}^{m} E_{t-1} Y_{t-1}^{m}\right)+\left(1-\alpha^{a}\right) \Pi_{t-1}^{a}+\left(1-\alpha^{m}\right) \Pi_{t-1}^{m}=G_{t} .
$$

The non-negativity constraint on foreign reserves is satisfied: ${ }^{3}$

$$
F_{t} \geq 0
$$

\subsubsection{Money Market}

The interest rate on foreign currency bonds and capital satisfy the following uncovered interest parity condition ${ }^{4}$ since firms are indifferent between borrowing from abroad and borrowing from domestic households:

$$
1+i_{1}=\left(1+i^{*}\right) E_{2}^{e} / E_{1}
$$

\footnotetext{
${ }^{3}$ Monetary policy variables were dropped from the original working paper version of Nakatani (2017a) to simplify the structure of the model and focus on exchange rate policy.

${ }^{4}$ We use the uncovered interest parity condition rather than the covered interest parity condition because the forward market is not well-developed in PNG.
} 
where $E_{2}^{e}$ is the expected nominal exchange rate in period 2. If a parallel exchange rate market exists, the exchange rate in this market exhibits a higher premium under FX rationing, implying a shadow exchange rate, $\tilde{E}_{t}$. Thus, if a parallel market emerges under $\mathrm{FX}$ rationing, the interest parity condition holds for this shadow exchange rate, i.e., $1+i_{1}=\left(1+i^{*}\right) E_{2}^{e} / \widetilde{E}_{1}$. If $i_{1}$ is decreased, but $E_{2}^{e}$ is unchanged, then $E_{1}$ must increase (kina depreciation).

\subsubsection{Balance of Payments Identity}

The BOP identity in domestic currency is written as:

$$
P_{t}^{a, f} E_{t} Y_{t}^{a, f}+P_{t}^{m} E_{t} Y_{t}^{m, f}-P_{t}^{i} E_{t} Y_{t}^{i}=\alpha^{a} \Pi_{t}^{a}+\alpha^{m} \Pi_{t}^{m}+\left(1+i^{*}\right) E_{t} B_{t-1}-E_{t} B_{t}+\Delta F_{t} E_{t}
$$

where $\Delta F_{t}=F_{t}-F_{t-1}$. Dividing this by $E_{t}$, the BOP identity can be rewritten in foreign currency (i.e., U.S. dollars) as:

$$
P_{t}^{a, f} Y_{t}^{a, f}+P_{t}^{m} Y_{t}^{m, f}-P_{t}^{i} Y_{t}^{i}=\left(\alpha^{a} \Pi_{t}^{a}+\alpha^{m} \Pi_{t}^{m}\right) / E_{t}+\left(1+i^{*}\right) B_{t-1}-B_{t}+\Delta F_{t} .
$$

\subsubsection{Equilibrium}

The initial equilibrium is defined as a set of allocations

$\left\{L_{1}^{a}, L_{1}^{m}, Y_{1}^{a}, Y_{1}^{a, d}, Y_{1}^{a, f}, Y_{1}^{m}, Y_{1}^{m, d}, Y_{1}^{m . f}, Y_{1}^{i}, K_{1}, I_{1}, B_{1}, \Pi_{1}^{a}, \Pi_{1}^{m}, F_{1}\right\}$ and a set of prices and wages as well as interest and exchange rates $\left\{P_{1}^{a, f}, P_{1}^{a, d}, P_{1}^{m}, W_{1}^{a}, W_{1}^{m}, i_{1}, E_{1}, R_{1}\right\}$, given

$\left\{P_{0}^{a, f}, P_{0}^{m}, P_{1}^{F}, P_{1}^{i}, Y_{0}^{a, f}, Y_{0}^{m}, Y_{1}^{F}, A_{1}^{a}, A_{1}^{m}, K_{0}, B_{0}, F_{0}, \Pi_{0}^{a}, \Pi_{0}^{m}, i_{0}, i^{*}, E_{2}^{e}, \tau, \propto, \alpha^{a}, \alpha^{m}, \vartheta^{a}, \vartheta^{m}, \vartheta^{i}, \beta, \delta\right\}$ such that:

1. $\quad\left\{L_{1}^{a}, L_{1}^{m}, Y_{1}^{a}, Y_{1}^{a, d}, Y_{1}^{a, f}, Y_{1}^{m}, Y_{1}^{m, d}, Y_{1}^{m . f}, K_{1}, B_{1}, \Pi_{1}^{a}, \Pi_{1}^{m}\right\}$ solve the firms' problem and satisfy Equations (1) - (12);

2. $\quad\left\{L_{1}^{a}, L_{1}^{m}, Y_{1}^{a, d}, Y_{1}^{m, d}, Y_{1}^{i}, K_{1}\right\}$ solve the household's problem and satisfy Equations (13) - (18);

3. $\left\{G_{1}, F_{1}\right\}$ solve the government's problem and satisfy Equations (19) and (20);

4. $\left\{E_{1}, F_{1}\right\}$ satisfy the interest parity condition of Equation (21) and the BOP identity of Equation (22).

The model can be solved with the number of endogenous variables matching the number of equilibrium conditions ( 22 in total).

\subsection{Commodity Price Shocks in Period 1}

The remainder of the paper focuses on the external adjustment to a negative commodity price shock. Under negative shocks to commodity prices such that $P_{1}^{a, f, s}<P_{1}^{a, f}$ and $P_{1}^{m, s}<P_{1}^{m}$, where superscript " $s$ " denotes a variable after a shock, the BOP identity in U.S. dollars (22) will be

$$
P_{1}^{a, f, s} Y_{1}^{a, f}+P_{1}^{m, s} Y_{1}^{m, f}-P_{1}^{i} Y_{1}^{i}=\frac{\left(\alpha^{a} \pi_{1}^{a, s}+\alpha^{m} \pi_{1}^{m, s}\right)}{E_{1}}+\left(1+i^{*}\right) B_{t-1}-B_{t}+\Delta F_{1}^{s} .
$$

Subtracting (23) from (22), we find that negative commodity price shocks reduce foreign reserves by:

$$
F_{1}-F_{1}^{S}=\Delta P_{1}^{a, f} Y_{1}^{a, f}+\Delta P_{1}^{m} Y_{1}^{m, f}-(1-\tau)\left(\alpha^{a} \Delta P_{1}^{a, f} Y_{1}^{a, f}+\alpha^{m} \Delta P_{1}^{m} Y_{1}^{m}\right) / E_{1}
$$


where $\Delta P_{1}^{a, f} \equiv P_{1}^{a, f}-P_{1}^{a, f, s}$ and $\Delta P_{1}^{m} \equiv P_{1}^{m}-P_{1}^{m, s}$.

\subsection{Exchange Rate and FX Intervention Policy in Period 1}

We discuss four exchange rate and FX intervention policy options in response to the BOP crisis caused by the negative commodity price shocks. The focus is strictly on the effect of shocks on the external balance, any effects on domestic activity being delayed to period 2 (e.g., the tax revenue shortfall materializes in period 2). An equilibrium in period 1 is defined on the government's FX market policy response.

\subsubsection{Fixed Exchange Rate with No Intervention: Severe FX Rationing}

If the central bank does not sell reserves into the FX market and does not change the exchange rate and the interest rate in the face of shocks, import volume must decrease by the following amount:

$$
Y_{1}^{i}-Y_{1}^{i, s}=\frac{\Delta P_{1}^{a, f} Y_{1}^{a, f}+\Delta P_{1}^{m} Y_{1}^{m, f}-(1-\tau)\left(\alpha^{a} \Delta P_{1}^{a, f} Y_{1}^{a, f}+\alpha^{m} \Delta P_{1}^{m} Y_{1}^{m}\right) / E_{1}}{P_{1}^{i}} .
$$

If importers do not reduce orders, some orders are unmet and become backlogs. In this case, imports are fully compressed by the shortage of FX. The equilibrium condition (22) is replaced by (23) and the amount of imports is equivalent to $Y_{1}^{i, s}$ in period 1.

\subsubsection{Fixed Exchange Rate with Partial Intervention: Modest FX Rationing}

If the central bank sells an amount $\Delta F_{1}^{*}$ of reserves in the FX market without changing the exchange rate, the amount of import compression is smaller than under the previous case (25):

$$
Y_{1}^{i}-Y_{1}^{i, *}=\frac{\Delta P_{1}^{a, f} Y_{1}^{a, f}+\Delta P_{1}^{m} Y_{1}^{m, f}-(1-\tau)\left(\alpha^{a} \Delta P_{1}^{a, f} Y_{1}^{a, f}+\alpha^{m} \Delta P_{1}^{m} Y_{1}^{m}\right) / E_{1}-\Delta F_{1}^{*}}{P_{1}^{i}} .
$$

In this modest FX rationing case, the equilibrium condition (22) is replaced by

$$
P_{1}^{a, f, s} Y_{1}^{a, f}+P_{1}^{m, s} Y_{1}^{m, f}-P_{1}^{i} Y_{1}^{i, *}=\frac{\left(\alpha^{a} \pi_{1}^{a, s}+\alpha^{m} \pi_{1}^{m, s}\right)}{E_{1}}+\left(1+i^{*}\right) B_{t-1}-B_{t}+\Delta F_{1}^{s}+\Delta F_{1}^{*}
$$

in period 1 and import volume is $Y_{1}^{i, *}$, which is greater than under the previous case of severe FX rationing (i.e., $Y_{1}^{i, *}>Y_{1}^{i, s}$ ).

\subsubsection{Fixed Exchange Rate with Full Intervention: No FX Rationing}

If the central bank wants to clear all backlogs of imports, it must sell reserves in the FX market in the amount given by (24), which we define as $\Delta F_{1}^{f u l l}$, to fully offset the loss of FX inflows caused by drops in commodity prices. The BOP identity in the equilibrium of period 1 becomes:

$$
P_{1}^{a, f, s} Y_{1}^{a, f}+P_{1}^{m, s} Y_{1}^{m, f}-P_{1}^{i} Y_{1}^{i}=\frac{\left(\alpha^{a} \pi_{1}^{a, s}+\alpha^{m} \pi_{1}^{m, s}\right)}{E_{1}}+\left(1+i^{*}\right) B_{t-1}-B_{t}+\Delta F_{1}^{s}+\Delta F_{1}^{f u l l},
$$

so that import volume does not change in the face of commodity price shocks. This policy is feasible as long as the government has enough reserves to clear all backlogs of import orders. In other words, the central bank should satisfy the non-negativity constraint for foreign reserves (20), which becomes in this case:

$$
F_{1}-\left\{\Delta P_{1}^{a, f} Y_{1}^{a, f}+\Delta P_{1}^{m} Y_{1}^{m, f}-(1-\tau)\left(\alpha^{a} \Delta P_{1}^{a, f} Y_{1}^{a, f}+\alpha^{m} \Delta P_{1}^{m} Y_{1}^{m, f}\right)\right\} / E_{1} \geq 0 .
$$




\subsubsection{Flexible Exchange Rate with Monetary Autonomy}

Another way to deal with the BOP problem is to use exchange rate flexibility as a shock absorber. In the case of a perfectly flexible exchange rate policy, all equilibrium conditions in period 1 are the same as under the initial equilibrium except that the exchange rate is set to the market clearing level (i.e., $E_{1}^{\text {flex }}>E_{1}$ ). To analyze the effects of a flexible exchange rate policy, we take the derivative of the BOP identity in U.S. dollars (22) with respect to the exchange rate:

$$
P_{t}^{a, f} \frac{\partial Y_{t}^{a, f}}{\partial E_{t}}+P_{t}^{m, f} \frac{\partial Y_{t}^{m, f}}{\partial E_{t}}-P_{t}^{i} \frac{\partial Y_{t}^{i}}{\partial E_{t}}=\frac{\frac{\partial\left(\alpha^{a} \pi_{t}^{a}+\alpha^{m} \pi_{t}^{m}\right)}{\partial E_{t}} E_{t}-\left(\alpha^{a} \pi_{t}^{a}+\alpha^{m} \pi_{t}^{m}\right)}{E_{t}^{2}}+\frac{\partial \Delta F_{t}}{\partial E_{t}} .
$$

Defining $\xi^{i}$ as the elasticity of good $i$ with respect to the exchange rate, we can rewrite (30) as follows:

$$
P_{t}^{a, f} \xi^{a} \frac{Y_{t}^{a, f}}{E_{t}}+P_{t}^{m, f} \xi^{m} \frac{Y_{t}^{m, f}}{E_{t}}-P_{t}^{i} \xi^{i} \frac{Y_{t}^{i}}{E_{t}}=\left\{\alpha^{a}\left(\frac{\partial \pi_{t}^{a}}{\partial E_{t}} E_{t}-\pi_{t}^{a}\right)+\alpha^{m}\left(\frac{\partial \pi_{t}^{m}}{\partial E_{t}} E_{t}-\pi_{t}^{m}\right)\right\} / E_{t}^{2}+\xi^{\Delta F} \frac{\Delta F_{t}}{E_{t}} .
$$

Multiplying both sides by $E_{t}$, we get:

$$
\xi^{a} P_{t}^{a, f} Y_{t}^{a, f}+\xi^{m} P_{t}^{m, f} Y_{t}^{m, f}-\xi^{i} P_{t}^{i} Y_{t}^{i}=\Gamma_{t}+\xi^{\Delta F} \Delta F_{t},
$$

where:

$$
\begin{gathered}
\Gamma_{t}= \\
\alpha^{a}\left\{(1-\tau) \xi^{a} P_{t}^{a, f} Y_{t}^{a, f}-\frac{P_{t}^{a, d} Y_{t}^{a, d}-W_{t}^{a} L_{t}^{a}}{E_{t}}\right\}+ \\
\alpha^{m}\left\{(1-\tau) \xi^{m} P_{t}^{m, f} Y_{t}^{m, f}-\frac{-W_{t}^{m} L_{t}^{m}-\left(1+i_{t-1}^{B}\right) B_{t-1}+B_{t}+(1-\delta) K_{t-1}-K_{t}}{E_{t}}\right\} .
\end{gathered}
$$

$\Gamma_{t}$ represents the increase in dividend payments to foreign investors resulting from higher profits due to (i) lower costs due to valuation effects for domestic currency components and (ii) increased export volumes. In the empirical analysis to come, we show that both agricultural and mining exports increase $\left(\xi^{a}>0\right.$ and $\left.\xi^{m}>0\right)$ and imports decrease $\left(\xi^{m}<0\right)$ when there is a currency depreciation. Similarly, the left-hand side of (32) reflects an increase in both agricultural and mining exports and a decrease in imports. The total change in the trade account (given by the left hand side of (32)) must equal the sum of the increase in dividend payments to foreign investors and the change in foreign reserves.

Monetary policy can also be used to affect exchange rate dynamics under the flexible exchange rate regime. The interest parity condition (21) indicates that the central bank can lower the interest rate $i_{1}$ to induce currency depreciation. In fact, Nakatani (2017b) used panel data on 51 developing countries, including PNG, and found that a one percent decrease in the policy interest rate is associated with a one percent depreciation of domestic currency. This monetary easing is appropriate when the economy is hit by negative commodity price shocks because the inflation rate is falling and hence there is more room for accommodative monetary policy to support the economy. ${ }^{5}$ However, such loose monetary policy and the resulting exchange rate depreciation may lead to higher inflation depending on the degree of exchange rate passthrough, and monetary policy may then need to be tightened after commodity price shocks.

\footnotetext{
${ }^{5}$ Nakatani (2018a) found that lowering the policy interest rate in fixed exchange rate regimes is associated with lower probability of BOP crises.
} 


\subsection{Welfare Analysis of FX Rationing in Period 1}

To understand the welfare impact of FX rationing, it is helpful to consider the shadow exchange rate that households face under import compression. We define the shadow exchange rate, $\tilde{E}_{t}$, as the exchange rate that would prevail if floating were to determine equilibrium in the imported goods market. Figure 6 illustrates the shadow exchange rate in three FX rationing cases, severe, modest, or no rationing corresponding to no, partial, and full intervention by the central bank in the FX market. Suppose that the supply of imported goods is inelastic to its price; in other words, the price of imported goods in foreign currency units is exogenously determined in the global market, which is a plausible assumption for a small open economy. Further suppose a linear demand curve for simplicity. The initial equilibrium volume of imports is determined at the intersection of demand and supply curves, $Y_{1}^{i}$. If there is a negative commodity price shock and the central bank does not intervene in the FX market, import volume is compressed to $Y_{1}^{i, s}$ due to the FX shortage. In this case, households face the high shadow exchange rate, $\widetilde{E}_{1}^{s}$, for import price, $P_{1}^{i} \tilde{E}_{1}^{s}$, as shown in the figure. Next, if the central bank provides FX partially to offset the effect of negative commodity price shocks, imports are higher $\left(Y_{1}^{i, *}>Y_{1}^{i, s}\right)$ and the shadow exchange rate is lower than in the case without intervention $\left(\tilde{E}_{1}^{*}<\tilde{E}_{1}^{s}\right)$. Finally, if the full amount of FX is supplied by the central bank to meet all import orders determined at the initial equilibrium, imports remain unchanged at $Y_{1}^{i}$.

For each case, consumer welfare loss is depicted by the trapezoidal shaded area below the demand curve and above the supply curve. The welfare loss is larger under severe FX rationing (red shaded area) than under modest rationing (light blue shaded area). This welfare loss is larger when the price elasticity of import demand is higher (i.e., steeper slope of demand curve).

The relationship between the shadow exchange rate premium, which is defined as the shadow exchange rate minus the actual exchange rate, and the amount of FX intervention is shown in Figure 7. The more the central bank rations FX, the higher the shadow exchange rate premium becomes. If a parallel exchange rate market emerges under the FX rationing, the shadow exchange rate prevails in this market and the resulting import price inflation is $P_{1}^{i} \tilde{E}_{1}$.

Figure 6. Welfare Loss by Import Compression

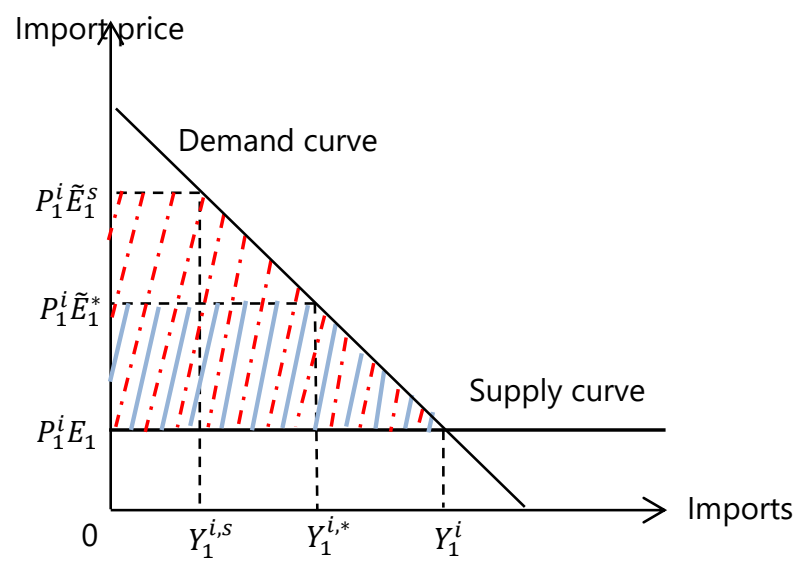

Figure 7. Shadow Exchange Rate Premium

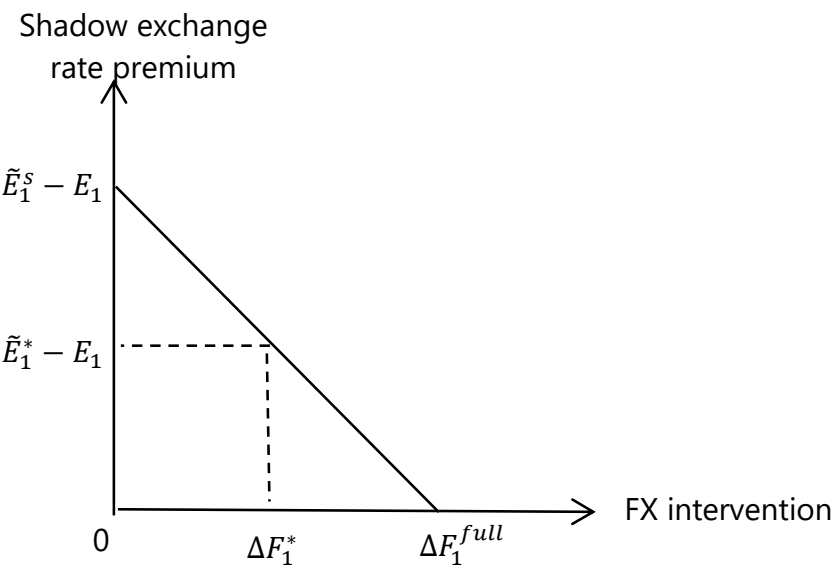




\subsection{Response of Agents in Period 2}

Let the commodity price shocks be permanent such that commodity prices remain the same in period 2 as in period 1 ; formally, $P_{2}^{a, f}=P_{1}^{a, f, s}$ and $P_{2}^{m}=P_{1}^{m, s}$. A number of equilibrium conditions in period 2 will be affected by the outcome of the price shocks and FX market policy response of period 1.

First, low commodity prices reduce government tax revenues from resource companies, which in turn lead to lower government expenditures to maintain the budget balance (Equation [19]). Government revenues and expenditures decline by the following amount:

$$
\Delta G_{2}=E_{1}\left[\tau\left(\Delta P_{1}^{a, f} Y_{1}^{a, f}+\Delta P_{1}^{m} Y_{1}^{m}\right)+(1-\tau)\left\{\left(1-\alpha^{a}\right) \Delta P_{1}^{a, f} Y_{1}^{a, f}+\left(1-\alpha^{m}\right) \Delta P_{1}^{m} Y_{1}^{m}\right\}\right] .
$$

As a result of the reduced government lump-sum transfer, household income declines, and therefore so, too, do household consumption and goods imports, as given by Equation (13). Note that the response of consumption depends on the duration of commodity price shocks. If the negative commodity price shock is permanent as assumed in our model, households are forced to reduce consumption faced with permanent income decreases. As such, the negative commodity price shock can transmit to the real economy not only through the external adjustment process but also through the domestic side via fiscal consolidation. This effect is prominent in resource-rich economies because they tend to rely heavily on resource revenues to fund their budgets.

Second, the policy strategy chosen by the central bank in period 1 will have consequences for household behavior. Specifically, if the central bank adopts a flexible exchange rate policy, the domestic currency will depreciate in period $2\left(E_{2}>E_{1}\right)$ to clear all markets, and households will thus face higher domestic prices for imported goods. By contrast, if the authority rations FX under a fixed exchange rate $\left(E_{2}=E_{1}\right)$, the household optimization problem includes the following additional constraint on import volume:

$$
Y_{2}^{i} \leq Y_{2}^{i, R a t i o n}
$$

where $Y_{2}^{i, \text { Ration }}$ is the upper limit on imports in period 2, as determined by the degree of FX intervention by the central bank. Given the same import price due to the fixed exchange rate, in the FX rationing case, the household optimization problem results in a corner solution of $Y_{2}^{i}=Y_{2}^{i, \text { Ration }}$. An example, assuming constant elasticity of substitution in the household utility function, is presented in Appendix B.

Finally, there is no issuance of bonds $\left(B_{2}=0\right)$ in period 2 because the model ends in this period.

\section{EMPIRICAL ANALYsIS}

As shown in the theoretical model, if a country has high elasticities of exports and imports with respect to exchange rates, currency depreciation can be an effective policy tool for responding to negative export price shocks. Conversely, if a country's exports are not responsive to exchange rates, a flexible exchange rate is not a very good solution. For understanding policy options, it is important to estimate the elasticities of exports and imports with respect to exchange rates. Thus, we now turn to analyzing the effects of exchange rates on PNG's trade volumes, using commodity-level export volume data and overall import volume data. 


\subsection{Export Elasticity}

\subsubsection{Time Series Analysis}

We estimate export supply elasticities with respect to real exchange rates for each of PNG's export commodities. We follow a standard approach by regressing export volume on foreign demand and REER as the explanatory variables, controlling for supply shocks. Our estimating equations are reduced-form versions of Equations (4) and (10). We use the Southern Oscillation Index (SOI) to capture supply-side weather shocks (e.g., drought and El Niño), as is common in the literature (Cashin, Mohaddes and Raissi 2017). Summary statistics for each variable are shown in Table 1.

Unit root tests indicate the presence of unit roots for most of the variables, as shown in Table 2. For this reason, we use cointegration techniques to estimate the elasticity of each commodity export with respect to real exchange rates. Cointegration test results shown in Table 3 confirm that variables are cointegrated. We use Engel-Granger type cointegration tests for individual export commodities. The Engel-Granger test is preferred to the Johansen test because we are interested in the cointegration relationship for each individual commodity rather than for the system as a whole. The test results in Table 3 show that some commodities (gold, oil, coffee, palm oil, and tea) are cointegrated at the 5 percent level of significance. Since it is known that Engel-Granger cointegration tests have a tendency to accept the null hypothesis of no cointegration, we further test for the presence of cointegration based on an error correction model (ECM). We include the error correction term, which is a residual of the long-run cointegration equation, in the short-run estimating equation reflected in Table 4. The coefficients on the error correction term are negative and statistically significant at the 5 percent level for 11 of 13 export commodities, confirming the presence of cointegration for most commodity exports.

Results of Dynamic Ordinary Least Squares (DOLS) are shown in Table 5. The DOLS estimator corrects for possible simultaneity bias among the regressors and yields long-run elasticity estimates (Stock and Watson 1993). The results show that some commodities - copper, cocoa, coffee, rubber, tea, and copra oil - have appropriately signed and statistically significant elasticities with respect to the real exchange rate. For coffee, the elasticity with respect to REER is -0.52 , so a 1 percent depreciation of the REER is associated with an increase in the volume of exports of about 0.5 percent. The elasticity for cocoa is similar, whereas elasticities for copper, copra oil, and tea exceed one. Elasticities with respect to foreign demand are more dominant for palm oil and marine products. Our elasticity estimate for palm oil with respect to foreign demand is 1.1, which is very close to the result obtained by Aba, Aipi and Irau (2012c). By contrast, the ECM results presented in Table 4 imply that only copper responds strongly to the exchange rates in the short-run.

As a robustness check, we further estimate elasticities using another cointegration regression method, the Fully Modified OLS (FMOLS) method, which corrects for endogeneity and serial correlation (Phillips and Hansen 1990). The results, presented in Table 6, do not substantially differ from those reported in Table 5. For example, the elasticity of coffee with respect to the REER is -0.72 versus -0.52 . In addition, the FMOLS elasticity estimates with respect to foreign demand are statistically significant for palm oil, rubber, logs, and marine products. 
Table 1. Summary Statistics for Export Regression Variables

\begin{tabular}{|c|c|c|c|c|c|c|c|c|c|c|c|c|c|c|c|c|}
\hline Variable & Gold & Copper & Oil & Silver & Copra & Cocoa & Coffee & $\begin{array}{l}\text { Palm } \\
\text { Oil }\end{array}$ & Rubber & Tea & $\begin{array}{c}\text { Copra } \\
\text { Oil } \\
\end{array}$ & Logs & $\begin{array}{c}\text { Marine } \\
\text { Products }\end{array}$ & REER & $\begin{array}{c}\text { Foreign } \\
\text { Demand }^{1} \\
\end{array}$ & SOI \\
\hline Period & $\begin{array}{l}1990- \\
2015\end{array}$ & $\begin{array}{l}1990- \\
2015\end{array}$ & $\begin{array}{l}1992- \\
2015 \\
\end{array}$ & $\begin{array}{l}1992- \\
2015\end{array}$ & $\begin{array}{l}1976- \\
2015\end{array}$ & $\begin{array}{l}1976- \\
2015 \\
\end{array}$ & $\begin{array}{l}1976- \\
2015\end{array}$ & $\begin{array}{l}1976- \\
2015 \\
\end{array}$ & $\begin{array}{l}1990- \\
2015\end{array}$ & $\begin{array}{l}1990- \\
2015\end{array}$ & $\begin{array}{l}1976- \\
2015\end{array}$ & $\begin{array}{l}1990- \\
2015\end{array}$ & $\begin{array}{l}1990- \\
2015 \\
\end{array}$ & $\begin{array}{l}1980- \\
2015\end{array}$ & $\begin{array}{l}1980- \\
2015 \\
\end{array}$ & $\begin{array}{l}1980- \\
2015\end{array}$ \\
\hline Unit & tons & $\begin{array}{l}\text { thousand } \\
\text { tons }\end{array}$ & $\begin{array}{l}\text { thousand } \\
\text { barrels }\end{array}$ & tons & $\begin{array}{l}\text { thousand } \\
\text { tons }\end{array}$ & $\begin{array}{l}\text { thousand } \\
\text { tons }\end{array}$ & $\begin{array}{l}\text { thousand } \\
\text { tons }\end{array}$ & $\begin{array}{l}\text { thousand } \\
\text { tons }\end{array}$ & $\begin{array}{l}\text { thousand } \\
\text { tons }\end{array}$ & $\begin{array}{c}\text { thousand } \\
\text { tons }\end{array}$ & $\begin{array}{l}\text { thousand } \\
\text { tons }\end{array}$ & $\begin{array}{c}\text { thousand } \\
\text { cubic } \\
\text { meters }\end{array}$ & $\begin{array}{l}\text { thousand } \\
\text { tons }\end{array}$ & $\begin{array}{c}\text { index } \\
2010=100\end{array}$ & $\begin{array}{c}\text { billion } \\
\text { international } \\
\text { dollars }\end{array}$ & index \\
\hline Mean & 58.3 & 165.1 & 19556 & 55.6 & 57.3 & 36.00 & 57.2 & 248.0 & 3.80 & 5.65 & 37.8 & 2318.0 & 30.17 & 108.38 & 2354.3 & -1.54 \\
\hline Median & 58.2 & 176.9 & 14534 & 53.2 & 58.6 & 35.35 & 54.8 & 238.2 & 3.75 & 5.85 & 38.2 & 2375.4 & 17.75 & 109.76 & 2295.9 & -2.15 \\
\hline Max & 72.8 & 230.6 & 45843 & 92.6 & 103.5 & 53.30 & 85.0 & 571.9 & 5.40 & 9.30 & 62.0 & 3868.0 & 95.40 & 138.00 & 4153.2 & 13.30 \\
\hline Min & 33.6 & 46.4 & 5823 & 35.0 & 8.4 & 26.00 & 37.0 & 24.5 & 2.20 & 1.30 & 11.1 & 990.2 & 1.30 & 77.27 & 778.4 & -13.08 \\
\hline Std. Dev. & 8.9 & 48.7 & 12170 & 12.2 & 30.0 & 7.05 & 11.6 & 160.5 & 0.88 & 2.00 & 11.4 & 849.7 & 29.00 & 18.48 & 998.5 & 7.15 \\
\hline
\end{tabular}

Note 1: Foreign Demand variable is calculated as a weighted average of GDP in major trading partners (Australia, Japan, China, Germany, and Korea) that account for 77 percent of PNG's export market.

Sources: Export volumes from BPNG; REER and Foreign Demand from the IMF; SOI from the Australian government.

Table 2. Unit Root Tests for Export Regression Variables

\begin{tabular}{|c|c|c|c|c|c|c|c|c|c|c|c|c|c|c|c|c|c|}
\hline $\log ($ Variable $)$ & $\begin{array}{l}\text { Trend for } \\
\text { Individual }\end{array}$ & Gold & Copper & Oil & Silver & Copra & Cocoa & Coffee & $\begin{array}{c}\text { Palm } \\
\text { Oil }\end{array}$ & Rubber & Tea & $\begin{array}{c}\text { Copra } \\
\text { Oil } \\
\end{array}$ & Logs & $\begin{array}{c}\text { Marine } \\
\text { Products } \\
\end{array}$ & REER & $\begin{array}{l}\text { Foreign } \\
\text { Demand } \\
\end{array}$ & SOI \\
\hline \multirow{2}{*}{ ADF Stat } & \multirow[t]{2}{*}{ No } & $\begin{array}{c}-4.70 \\
* * *\end{array}$ & -0.44 & -0.56 & $\begin{array}{c}-2.93 \\
*\end{array}$ & -1.41 & $\begin{array}{c}-2.68 \\
*\end{array}$ & $\begin{array}{c}-3.79 \\
* * *\end{array}$ & $\begin{array}{l}-3.71 \\
* * *\end{array}$ & -2.26 & 1.77 & -1.56 & -1.93 & -1.16 & -2.12 & $\begin{array}{c}-5.21 \\
* * *\end{array}$ & $\begin{array}{l}-4.12 \\
* * *\end{array}$ \\
\hline & & $(0.00)$ & $(0.89)$ & $(0.86)$ & $(0.06)$ & $(0.57)$ & $(0.09)$ & $(0.01)$ & $(0.01)$ & $(0.19)$ & $(1.00)$ & $(0.49)$ & $(0.31)$ & $(0.67)$ & $(0.24)$ & $(0.00)$ & $(0.00)$ \\
\hline \multirow{2}{*}{ ADF Stat } & \multirow{2}{*}{ Yes } & $\begin{array}{c}-4.39 \\
* * *\end{array}$ & -1.00 & $\begin{array}{c}-8.83 \\
* * *\end{array}$ & $\begin{array}{l}-5.44 \\
* * *\end{array}$ & $\begin{array}{c}-3.98 \\
* *\end{array}$ & $\begin{array}{c}-3.25 \\
*\end{array}$ & $\begin{array}{c}-3.99 \\
* *\end{array}$ & -2.21 & -1.36 & 1.24 & -1.61 & -2.29 & $\begin{array}{c}-3.52 \\
*\end{array}$ & 0.97 & -1.88 & $\begin{array}{l}-4.25 \\
* * *\end{array}$ \\
\hline & & $(0.01)$ & $(0.93)$ & $(0.00)$ & $(0.00)$ & $(0.02)$ & $(0.09)$ & $(0.02)$ & $(0.47)$ & $(0.85)$ & $(1.00)$ & $(0.77)$ & $(0.42)$ & $(0.06)$ & $(1.00)$ & $(0.64)$ & $(0.01)$ \\
\hline \multirow{2}{*}{$\begin{array}{l}\text { ADF Stat } \\
\text { 1st diff }\end{array}$} & \multirow[t]{2}{*}{ No } & $\begin{array}{c}-5.56 \\
* * *\end{array}$ & $\begin{array}{c}-4.79 \\
* * *\end{array}$ & $\begin{array}{c}-9.33 \\
* * *\end{array}$ & $\begin{array}{c}-4.99 \\
* * *\end{array}$ & $\begin{array}{c}-7.84 \\
* * *\end{array}$ & $\begin{array}{c}-7.21 \\
* * *\end{array}$ & $\begin{array}{c}-7.57 \\
* * *\end{array}$ & $\begin{array}{l}-8.27 \\
* * *\end{array}$ & $\begin{array}{c}-4.87 \\
* * *\end{array}$ & 0.01 & $\begin{array}{c}-5.83 \\
* * *\end{array}$ & $\begin{array}{c}-4.48 \\
* * *\end{array}$ & $\begin{array}{c}-2.73 \\
*\end{array}$ & -2.32 & $\begin{array}{c}-3.75 \\
* * *\end{array}$ & $\begin{array}{l}-6.75 \\
* * *\end{array}$ \\
\hline & & $(0.00)$ & $(0.00)$ & $(0.00)$ & $(0.00)$ & $(0.00)$ & $(0.00)$ & $(0.00)$ & $(0.00)$ & $(0.00)$ & $(0.95)$ & $(0.00)$ & $(0.00)$ & $(0.09)$ & $(0.17)$ & $(0.01)$ & $(0.00)$ \\
\hline \multirow{2}{*}{$\begin{array}{l}\text { ADF Stat } \\
\text { 1st diff }\end{array}$} & \multirow[t]{2}{*}{ Yes } & $\begin{array}{c}-3.82 \\
* *\end{array}$ & $\begin{array}{l}-5.02 \\
* * *\end{array}$ & $\begin{array}{c}-8.86 \\
* * *\end{array}$ & $\begin{array}{c}-3.81 \\
* *\end{array}$ & $\begin{array}{c}-7.72 \\
* * *\end{array}$ & $\begin{array}{c}-7.26 \\
* * *\end{array}$ & $\begin{array}{c}-7.96 \\
* * *\end{array}$ & $\begin{array}{c}-4.98 \\
* * *\end{array}$ & $\begin{array}{c}-5.36 \\
* * *\end{array}$ & $\begin{array}{c}-6.39 \\
* * *\end{array}$ & $\begin{array}{c}-6.00 \\
* * *\end{array}$ & $\begin{array}{c}-4.10 \\
* *\end{array}$ & -2.73 & $\begin{array}{c}-6.74 \\
* * *\end{array}$ & $\begin{array}{c}-4.48 \\
* * *\end{array}$ & $\begin{array}{l}-6.67 \\
* * *\end{array}$ \\
\hline & & $(0.03)$ & $(0.00)$ & $(0.00)$ & $(0.04)$ & $(0.00)$ & $(0.00)$ & $(0.00)$ & $(0.00)$ & $(0.00)$ & $(0.00)$ & $(0.00)$ & $(0.02)$ & $(0.24)$ & $(0.00)$ & $(0.01)$ & $(0.00)$ \\
\hline
\end{tabular}

* significant at $10 \%, * *$ significant at $5 \%, * * *$ significant at $1 \%$. The null hypothesis is the presence of a unit root. P-values are in parentheses. 
Table 3. Cointegration Tests for Export Variables

\begin{tabular}{|c|c|c|c|c|c|c|c|c|c|c|c|c|c|}
\hline $\log$ (Export Goods) & Gold & Copper & Oil & Silver & Copra & Cocoa & Coffee & Palm Oil & Rubber & Tea & Copra Oil & Logs & Marine Products \\
\hline ADF Stat & $\begin{array}{c}-4.68 \\
* *\end{array}$ & -1.95 & $\begin{array}{c}-6.43 \\
* * *\end{array}$ & -3.21 & -2.42 & -3.49 & $\begin{array}{c}-6.39 \\
* * *\end{array}$ & $\begin{array}{c}-4.60 \\
* *\end{array}$ & -3.18 & $\begin{array}{c}-5.20 \\
* * *\end{array}$ & -3.25 & -2.91 & $\begin{array}{c}-3.99 \\
*\end{array}$ \\
\hline & $(0.02)$ & $(0.76)$ & $(0.00)$ & $(0.22)$ & $(0.54)$ & $(0.13)-$ & $(0.00)$ & $(0.01)$ & $(0.23)$ & $(0.01)$ & $(0.19)$ & $(0.33)$ & $(0.06)$ \\
\hline
\end{tabular}

$*$ significant at $10 \%, * *$ significant at $5 \%$, *** significant at $1 \%$. The null hypothesis is no cointegration. P-values are in parentheses.

Table 4. Error Correction Model (ECM) Estimation Results

\begin{tabular}{|c|c|c|c|c|c|c|c|c|c|c|c|c|c|}
\hline dlog(Export Goods) & Gold & Copper & Oil & Silver & Copra & Cocoa & Coffee & Palm Oil & Rubber & Tea & Copra Oil & Logs & Marine Products \\
\hline \multirow{2}{*}{ Constant } & 0.03 & 0.04 & -0.06 & -0.03 & -0.13 & -0.06 & 0.08 & -0.07 & 0.03 & -0.07 & -0.11 & -0.09 & 0.33 \\
\hline & $(0.07)$ & $(0.04)$ & $(0.13)$ & $(0.08)$ & $(0.16)$ & $(0.05)$ & $(0.06)$ & $(0.07)$ & $(0.05)$ & $(0.10)$ & $(0.09)$ & $(0.10)$ & $(0.28)$ \\
\hline \multirow{2}{*}{ Error Correction Term } & $\begin{array}{c}\mathbf{- 0 . 7 1} \\
* *\end{array}$ & $\begin{array}{c}\mathbf{- 0 . 6 4} \\
* * * *\end{array}$ & $\begin{array}{c}-0.72 \\
*\end{array}$ & $\begin{array}{c}\mathbf{- 0 . 6 5} \\
* *\end{array}$ & $\begin{array}{c}-\mathbf{- 0 . 5 2} \\
* *\end{array}$ & $\begin{array}{c}\mathbf{- 0 . 5 8} \\
* *\end{array}$ & $\begin{array}{c}-1.23 \\
* * *\end{array}$ & $\begin{array}{c}\mathbf{- 0 . 9 3} \\
* * *\end{array}$ & $\begin{array}{c}-\mathbf{- 0 . 7 1} \\
* * *\end{array}$ & $\begin{array}{c}\mathbf{- 0 . 9 9} \\
* * *\end{array}$ & $\begin{array}{c}\mathbf{- 0 . 4 1} \\
* *\end{array}$ & -0.27 & $\begin{array}{c}-\mathbf{- 0 . 7 2} \\
* *\end{array}$ \\
\hline & $(0.28)$ & $(0.20)$ & $(0.41)$ & $(0.22)$ & $(0.21)$ & $(0.27)$ & $(\mathbf{0 . 2 3})$ & $(\mathbf{0 . 3 0})$ & $(0.22)$ & $(0.32)$ & $(0.19)$ & $(0.22)$ & $(\mathbf{0 . 3 0})$ \\
\hline \multirow{2}{*}{$\operatorname{dlog}(\mathrm{REER})$} & 0.03 & $\begin{array}{c}-1.20 \\
* *\end{array}$ & 0.46 & -0.10 & 1.03 & $\begin{array}{c}0.78 \\
* *\end{array}$ & 0.29 & $\begin{array}{c}0.96 \\
*\end{array}$ & $\begin{array}{l}1.21 \\
* * *\end{array}$ & 0.53 & 0.26 & 0.51 & -1.18 \\
\hline & $(0.41)$ & $(0.54)$ & $(0.83)$ & $(0.48)$ & $(1.13)$ & $(0.37)$ & $(0.41)$ & $(0.48)$ & $(0.33)$ & $(0.64)$ & $(0.64)$ & $(0.66)$ & $(1.77)$ \\
\hline \multirow{2}{*}{ dlog(Foreign Demand) } & -0.55 & -1.74 & 0.44 & 0.32 & 2.62 & 1.58 & -1.72 & $\begin{array}{c}\mathbf{3 . 3 9} \\
* *\end{array}$ & -1.01 & 0.75 & 1.62 & 3.93 & -4.76 \\
\hline & $(1.61)$ & $(2.05)$ & (3.34) & (1.94) & $(3.09)$ & $(1.01)$ & $(1.12)$ & (1.32) & $(1.24)$ & $(2.42)$ & $(1.74)$ & $(2.52)$ & (6.77) \\
\hline \multirow{2}{*}{ SOI } & -0.00 & 0.00 & -0.01 & 0.01 & 0.01 & 0.00 & -0.01 & -0.00 & $\begin{array}{c}-0.01 \\
* * *\end{array}$ & 0.00 & -0.01 & -0.00 & -0.01 \\
\hline & $(0.00)$ & $(0.00)$ & $(0.01)$ & $(0.01)$ & $(0.01)$ & $(0.00)$ & $(0.00)$ & $(0.00)$ & $(0.00)$ & $(0.00)$ & $(0.01)$ & $(0.01)$ & $(0.02)$ \\
\hline R-squared & 0.27 & 0.45 & 0.20 & 0.38 & 0.26 & 0.35 & 0.54 & 0.40 & 0.65 & 0.40 & 0.17 & 0.22 & 0.29 \\
\hline
\end{tabular}

$*$ significant at $10 \%, * *$ significant at $5 \%, * * *$ significant at $1 \%$. Standard errors are in parentheses. Bold numbers are statistically significant at the $5 \%$ level with expected signs. 
Table 5. Dynamic Ordinary Least Squares (DOLS) Estimation Results

\begin{tabular}{|c|c|c|c|c|c|c|c|c|c|c|c|c|c|}
\hline $\log ($ Export Goods $)$ & Gold & Copper & Oil & Silver & Copra & Cocoa & Coffee & Palm Oil & Rubber & Tea & Copra Oil & Logs & Marine Products \\
\hline \multirow{2}{*}{ Constant } & $\begin{array}{l}6.76 \\
* * *\end{array}$ & $\begin{array}{c}14.12 \\
* * *\end{array}$ & $\begin{array}{c}21.14 \\
* * *\end{array}$ & $\begin{array}{c}6.24 \\
*\end{array}$ & 0.10 & $\begin{array}{c}4.20 \\
* *\end{array}$ & $\begin{array}{l}5.65 \\
* * *\end{array}$ & $\begin{array}{c}-2.79 \\
*\end{array}$ & 1.53 & $\begin{array}{c}17.02 \\
* * *\end{array}$ & $\begin{array}{c}19.44 \\
* * *\end{array}$ & -4.67 & $\begin{array}{c}-32.71 \\
* * *\end{array}$ \\
\hline & $(2.30)$ & $(3.96)$ & $(3.05)$ & $(3.43)$ & $(5.42)$ & $(1.57)$ & $(1.38)$ & $(1.50)$ & $(1.93)$ & $(2.63)$ & $(4.67)$ & $(5.50)$ & $(8.17)$ \\
\hline \multirow[t]{2}{*}{$\log ($ REER $)$} & $\begin{array}{c}-0.57 \\
*\end{array}$ & $\begin{array}{c}-1.12 \\
* *\end{array}$ & 0.09 & 0.50 & $\begin{array}{l}2.11 \\
* * *\end{array}$ & $\begin{array}{c}-\mathbf{- 0 . 4 5} \\
* *\end{array}$ & $\begin{array}{c}-\mathbf{- 0 . 5 2} \\
* * *\end{array}$ & 0.01 & $\begin{array}{c}-\mathbf{- 0 . 6 7} \\
* *\end{array}$ & $\begin{array}{c}-\mathbf{- 2 . 0 8} \\
* * *\end{array}$ & $\begin{array}{c}-1.87 \\
* * * *\end{array}$ & 1.10 & -1.58 \\
\hline & $(0.29)$ & $(0.49)$ & $(0.39)$ & $(0.44)$ & $(0.71)$ & $(0.20)$ & $(\mathbf{0 . 1 8})$ & $(0.19)$ & $(0.24)$ & $(\mathbf{0 . 3 3})$ & $(\mathbf{0 . 6 0 )}$ & $(0.68)$ & $(1.01)$ \\
\hline \multirow{2}{*}{$\log ($ Foreign Demand $)$} & & -0.52 & $\begin{array}{c}-1.47 \\
* * *\end{array}$ & -0.59 & $\begin{array}{c}-0.74 \\
* * *\end{array}$ & 0.17 & 0.11 & $\begin{array}{c}1.10 \\
* * *\end{array}$ & $\begin{array}{c}0.38 \\
*\end{array}$ & $\begin{array}{c}-0.73 \\
* *\end{array}$ & $\begin{array}{c}-0.90 \\
* *\end{array}$ & $\begin{array}{c}0.93 \\
*\end{array}$ & $\begin{array}{l}\mathbf{5 . 3 2} \\
* * * *\end{array}$ \\
\hline & $(0.22)$ & $(0.38)$ & $(0.31)$ & $(0.35)$ & $(0.40)$ & $(0.12)$ & $(0.10)$ & $(0.11)$ & $(0.19)$ & $(0.25)$ & $(0.35)$ & $(0.53)$ & $(0.79)$ \\
\hline R-squared & 0.39 & 0.50 & 0.89 & 0.33 & 0.70 & 0.72 & 0.50 & 0.96 & 0.74 & 0.77 & 0.55 & 0.60 & 0.90 \\
\hline
\end{tabular}

$*$ significant at $10 \%, * *$ significant at $5 \%, * * *$ significant at $1 \%$. Standard errors are in parentheses. Bold numbers are statistically significant at the $5 \%$ level with expected signs.

Table 6. Fully Modified Ordinary Least Squares (FMOLS) Estimation Results

\begin{tabular}{|c|c|c|c|c|c|c|c|c|c|c|c|c|c|}
\hline $\log ($ Export Goods $)$ & Gold & Copper & Oil & Silver & Copra & Cocoa & Coffee & Palm Oil & Rubber & Tea & Copra Oil & Logs & Marine Products \\
\hline \multirow{2}{*}{ Constant } & $\begin{array}{l}5.77 \\
* * *\end{array}$ & $\begin{array}{c}17.01 \\
* * *\end{array}$ & $\begin{array}{c}26.32 \\
* * *\end{array}$ & $\begin{array}{l}5.43 \\
* * *\end{array}$ & 2.05 & $\begin{array}{c}3.95 \\
* *\end{array}$ & $\begin{array}{l}7.38 \\
* * *\end{array}$ & $\begin{array}{c}-4.81 \\
* * *\end{array}$ & $\begin{array}{c}2.88 \\
*\end{array}$ & $\begin{array}{c}17.51 \\
* * *\end{array}$ & $\begin{array}{c}16.61 \\
* * *\end{array}$ & -4.11 & $\begin{array}{c}-32.58 \\
* * *\end{array}$ \\
\hline & $(1.20)$ & $(2.68)$ & $(2.03)$ & $(1.82)$ & $(4.35)$ & $(1.38)$ & $(0.97)$ & $(1.44)$ & $(1.61)$ & $(1.83)$ & $(2.91)$ & $(2.77)$ & $(4.73)$ \\
\hline \multirow{2}{*}{$\log ($ REER $)$} & $\begin{array}{c}-\mathbf{- 0 . 6 1} \\
* * *\end{array}$ & $\begin{array}{c}-\mathbf{1 . 3 0} \\
* * *\end{array}$ & -0.23 & 0.50 & $\begin{array}{c}1.40 \\
* *\end{array}$ & -0.30 & $\begin{array}{c}-\mathbf{- 0 . 7 2} \\
* * *\end{array}$ & -0.11 & $\begin{array}{c}\mathbf{- 0 . 9 7} \\
* * *\end{array}$ & $\begin{array}{c}-2.26 \\
* * *\end{array}$ & $\begin{array}{c}-\mathbf{1 . 8 5} \\
* * *\end{array}$ & $\begin{array}{c}0.85 \\
*\end{array}$ & -1.07 \\
\hline & $(0.21)$ & $(0.46)$ & $(0.36)$ & $(0.32)$ & $(0.66)$ & $(0.21)$ & $(0.15)$ & $(0.22)$ & $(0.28)$ & $(\mathbf{0 . 3 2})$ & $(0.44)$ & $(0.48)$ & $(0.82)$ \\
\hline \multirow{2}{*}{$\log ($ Foreign Demand $)$} & 0.14 & $\begin{array}{c}-0.76 \\
* * *\end{array}$ & $\begin{array}{c}-1.96 \\
* * *\end{array}$ & $\begin{array}{c}-0.47 \\
* *\end{array}$ & $\begin{array}{c}-0.62 \\
* *\end{array}$ & 0.13 & 0.01 & $\begin{array}{l}1.40 \\
* * * *\end{array}$ & $\begin{array}{c}\mathbf{0 . 3 7} \\
* *\end{array}$ & $\begin{array}{c}-0.69 \\
* * *\end{array}$ & $\begin{array}{c}-0.57 \\
* * *\end{array}$ & $\begin{array}{l}\mathbf{0 . 9 9} \\
* * *\end{array}$ & $\begin{array}{l}\mathbf{5 . 0 7} \\
* * * *\end{array}$ \\
\hline & $(0.12)$ & $(0.27)$ & $(0.23)$ & $(0.21)$ & $(0.25)$ & $(0.08)$ & $(0.06)$ & $(0.08)$ & $(0.16)$ & $(0.18)$ & $(0.17)$ & $(\mathbf{0 . 2 8})$ & $(0.47)$ \\
\hline R-squared & 0.24 & 0.42 & 0.80 & 0.22 & 0.49 & 0.26 & 0.36 & 0.92 & 0.31 & 0.62 & 0.42 & 0.58 & 0.86 \\
\hline
\end{tabular}

$*$ significant at $10 \%, * *$ significant at $5 \%, * * *$ significant at $1 \%$. Standard errors are in parentheses. Bold numbers are statistically significant at the $5 \%$ level with expected signs. 


\subsubsection{Panel Analysis}

Next, we employ panel regression methods to estimate overall elasticities for PNG commodity exports. The results of three different panel unit root tests, in which we assume an individual unit root process, are shown in Table 7. Although the results indicate that there is a unit root in REER (and for some cases in export goods and foreign demand, especially when we include individual trends) and that all variables become stationary when taken in first difference, we do not make use of first differences when we conduct panel estimation for three reasons. First, to obtain a supply elasticity of exports with respect to the real exchange rate, we wish to include the log of REER as a regressor. Second, we can compare this overall elasticity estimate with those for individual commodities given previously. Third, as a theoretical principle, the real exchange rate approximates the equilibrium exchange rate in the long-run. For these reasons, we include the log level of REER as an explanatory variable following the standard empirical literature.

Table 7. Panel Unit Root Tests for Overall Exports

\begin{tabular}{|c|c|c|c|c|c|c|}
\hline Test Type & \multicolumn{2}{|c|}{ Im, Pesaran and Shin } & \multicolumn{2}{|c|}{ Maddala and $\mathrm{Wu}$} & \multicolumn{2}{|c|}{ Choi } \\
\hline Trend & No & Yes & No & Yes & No & Yes \\
\hline $\log$ (Exports) & $\begin{array}{c}-1.24 \\
(-14.51 * * *)\end{array}$ & $\begin{array}{c}-0.25 \\
(-13.80 * * *)\end{array}$ & $39.04 * *$ & $\begin{array}{c}30.19 \\
(205.05 * * *)\end{array}$ & $49.39 * * *$ & $\begin{array}{c}64.03 \\
(811.58 * * *)\end{array}$ \\
\hline $\log (\mathrm{REER})$ & $\begin{array}{c}0.43 \\
(-14.41 * * *) \\
\end{array}$ & $\begin{array}{c}8.01 \\
(-19.41 * * *)\end{array}$ & $\begin{array}{c}14.82 \\
(223.48 * * *)\end{array}$ & $\begin{array}{c}0.33 \\
(289.98 * * *)\end{array}$ & $\begin{array}{c}12.53 \\
(264.38 * * *)\end{array}$ & $\begin{array}{c}0.34 \\
\left(292.86^{* * *}\right)\end{array}$ \\
\hline $\begin{array}{c}\log (\text { Foreign } \\
\text { Demand })\end{array}$ & $-4.31 * * *$ & $\begin{array}{c}1.25 \\
(-7.64 * * *) \\
\end{array}$ & $59.27 * * *$ & $\begin{array}{c}11.54 \\
\left(101.95^{* * *}\right) \\
\end{array}$ & $206.94 * * *$ & $44.88 * *$ \\
\hline SOI & $-10.84 * * *$ & $-9.04 * * *$ & $162.79 * * *$ & $123.21 * * *$ & $159.78 * * *$ & $111.60 * * *$ \\
\hline
\end{tabular}

* significant at $10 \%, * *$ significant at $5 \%, * * *$ significant at $1 \%$. Test statistics for first differenced variables are in parentheses.

Results of panel cointegration tests following Pedroni (1999), presented in Table 8, show that three of the seven statistics do not reject the null hypothesis of no cointegration at the 5 percent level of significance. An alternative test proposed by Kao (1999) does not reject the null hypothesis either. In view of these results, we adopt alternative approaches to panel cointegration regression.

Table 8. Panel Cointegration Tests for Overall Exports

\begin{tabular}{|c|lc|}
\hline \multicolumn{3}{|c|}{ Pedroni’s Test Statistics } \\
\hline Panel variance ratio statistic & 0.118 & $(0.453)$ \\
\hline Panel rho-statistic & -1.015 & $(0.155)$ \\
\hline Panel Phillips-Perron statistic & $-4.926 * * *(0.000)$ \\
\hline Panel ADF t-statistic & $-2.647 * * *(0.004)$ \\
\hline Group mean rho-statistic & 0.606 & $(0.728)$ \\
\hline Group mean Phillips-Perron statistic & $-6.583 * * *(0.000)$ \\
\hline Group mean ADF t-statistic & $-4.143 * * *(0.000)$ \\
\hline \multicolumn{2}{|c|}{ Kao's Test Statistic } \\
\hline ADF t-statistic & -0.297 \\
\hline
\end{tabular}

* significant at $10 \%, * *$ significant at $5 \%, * * *$ significant at $1 \%$. Critical probabilities are in parentheses.

We employ three panel estimation methods. The first is FMOLS for panel cointegration analysis which produces asymptotically unbiased estimates for both the standard case without intercepts and the fixed effects model with heterogeneous intercepts (Pedroni 2000). The second is the fixed effects (FE) model of Driscoll and Kraay (1998) which accommodates cross-sectional inter- 
dependence such as may exist for agricultural and mining commodities. For instance, if cocoa prices increase relative to coffee prices, farmers shift production from coffee to cocoa. Similar shifts in production can occur in mining because some major mines produce multiple metals. Our third method is two-stage least squares (2SLS) with instrumental variables to control for potential endogeneity between the exchange rate and exports. We employ the lagged exchange rate as an instrument since this variable is strongly correlated with the current exchange rate but is exogenous in the sense of being predetermined. Table 9 presents results for each estimation method applied both to overall exports and to agricultural exports only. For commodity exports overall, the elasticity estimates with respect to the real exchange rate range from -0.30 under the FE model (a short-run estimate) to -0.43 under the FMOLS model (a long-run estimate). For agricultural exports, the elasticity estimates with respect to the real exchange rate range from 0.53 under the FE model to -0.71 under the 2SLS model. Thus, our panel regression analyses confirm that PNG commodity exports respond elastically to the real exchange rate, with the response slightly higher for agricultural commodities than for primary commodities overall.

Table 9. Panel Regression Results for Overall and Agricultural Exports

\begin{tabular}{|c|c|c|c|c|c|c|}
\hline Estimation Method & \multicolumn{2}{|c|}{ FMOLS } & \multicolumn{2}{|c|}{ Driscoll and Kraay FE } & \multicolumn{2}{|c|}{ 2SLS } \\
\hline Commodities & Overall & Agricultural & Overall & Agricultural & Overall & Agricultural \\
\hline Constant & - & - & $\begin{array}{c}1.998 * * * \\
(0.414)\end{array}$ & $\begin{array}{c}2.709 * * * \\
(0.565)\end{array}$ & $\begin{array}{c}2.311 * * * \\
(0.559)\end{array}$ & $\begin{array}{c}3.233 * * * \\
(0.602)\end{array}$ \\
\hline $\log ($ REER $)$ & $\begin{array}{c}-0.428 * * * \\
(0.128)\end{array}$ & $\begin{array}{c}-0.674 * * * \\
(0.153)\end{array}$ & $\begin{array}{c}-0.296 * * \\
(0.126)\end{array}$ & $\begin{array}{c}-0.533 * * \\
(0.210)\end{array}$ & $\begin{array}{c}-0.421 * * \\
(0.213)\end{array}$ & $\begin{array}{c}-0.709 * * * \\
(0.220)\end{array}$ \\
\hline $\log ($ Foreign Demand $)$ & $\begin{array}{c}0.322 * * \\
(0.152) \\
\end{array}$ & $\begin{array}{l}-0.012 \\
(0.027) \\
\end{array}$ & $\begin{array}{l}\mathbf{0 . 0 5 9} * \\
(\mathbf{0 . 0 3 2}) \\
\end{array}$ & $\begin{array}{l}-0.014 \\
(0.032) \\
\end{array}$ & $\begin{array}{c}0.051 \\
(0.038) \\
\end{array}$ & $\begin{array}{l}-0.036 \\
(0.035) \\
\end{array}$ \\
\hline SOI & - & - & $\begin{array}{c}0.002 * * \\
(0.001)\end{array}$ & $\begin{array}{c}0.003 * * \\
(0.001)\end{array}$ & $\begin{array}{c}0.002 \\
(0.002)\end{array}$ & $\begin{array}{l}0.003 * \\
(0.002)\end{array}$ \\
\hline Fixed Effects & Yes & Yes & Yes & Yes & Yes & Yes \\
\hline Observations & 379 & 227 & 384 & 232 & 379 & 227 \\
\hline R-squared & 0.98 & 0.89 & 0.29 & 0.55 & - & - \\
\hline $\begin{array}{c}\text { First-Stage Regression: } \\
\log (\operatorname{REER}(-1))\end{array}$ & - & - & - & 一 & $\begin{array}{c}0.951 * * * \\
(0.026)\end{array}$ & $\begin{array}{c}0.963 * * * \\
(0.034)\end{array}$ \\
\hline F Statistic & - & - & - & - & $482.61 * * *$ & $337.32 * * *$ \\
\hline
\end{tabular}

$*$ significant at $10 \%, * *$ significant at $5 \%$, $* * *$ significant at $1 \%$. Standard errors are in parentheses. Bold numbers are statistically significant at the $5 \%$ level with expected signs. Previous year's REER is used as an instrument in 2SLS estimation.

As a further check, we compute the weighted average of export elasticities with respect to the real exchange rate for the individual commodities, where the weights are export shares. We obtain a value of -0.43 from the DOLS estimates (Table 5) and -0.51 for the FMOLS estimates (Table 6). Comparing these estimates with those in Table 9, we conclude that our estimates of overall export elasticity with respect to the real exchange rate are robust at around -0.4 .

\subsection{Import Elasticity}

Next, we estimate import volume as a function of the REER controlling for domestic demand. Official PNG data do not contain a measure for real import volume. We therefore deflate the nominal value of imports using the import deflator from the IMF's Global Economic Environment database to derive a measure. Domestic demand is taken as real GDP minus exports (IMF 2015). 
Our real GDP series comes from the PNG National Statistical Office through 2014, with the IMF estimate used for 2015. Summary statistics are shown in Table 10.

Table 10. Summary Statistics for Import Regression Variables

\begin{tabular}{|c|c|c|c|}
\hline Variable & Imports & REER & $\begin{array}{c}\text { Domestic } \\
\text { Demand }\end{array}$ \\
\hline Period & $1990-2015$ & $1990-2015$ & $1990-2015$ \\
\hline Units & $2005=100$ & $2010=100$ & $\begin{array}{c}\text { million kina } \\
\text { constant price }\end{array}$ \\
\hline Mean & 146.5 & 100.9 & 15244 \\
\hline Median & 129.7 & 100.4 & 2860 \\
\hline Max & 299.6 & 131.0 & 44418 \\
\hline Min & 97.5 & 77.3 & 974 \\
\hline Std. Dev. & 54.4 & 15.8 & 17296 \\
\hline Source & BPNG, IMF & IMF & NSO, IMF \\
\hline
\end{tabular}

Note 1: Domestic Demand variable is calculated as real GDP minus exports.

Unit root test results presented in Table 11 show that for none of the variables can we consistently reject the null hypothesis of a unit root. Thus, we use cointegration techniques to estimate the import equation.

Table 11. Unit Root Tests for Import Regression Variables

\begin{tabular}{|c|c|c|c|c|}
\hline $\log$ (Variable) & $\begin{array}{c}\text { Trend for } \\
\text { Individual }\end{array}$ & Imports & REER & $\begin{array}{c}\text { Domestic } \\
\text { Demand }\end{array}$ \\
\hline ADF Stat & No & $\begin{array}{c}-2.02 \\
(0.28)\end{array}$ & $\begin{array}{c}-2.23 \\
(0.20)\end{array}$ & $\begin{array}{c}-0.72 \\
(0.82)\end{array}$ \\
\hline ADF Stat & Yes & $\begin{array}{c}-2.59 \\
(0.29)\end{array}$ & $\begin{array}{c}0.20 \\
(0.99)\end{array}$ & $\begin{array}{c}-2.25 \\
(0.44)\end{array}$ \\
\hline ADF Stat & \multirow{2}{*}{ No } & $\begin{array}{c}-3.18^{* *} \\
(0.03)\end{array}$ & $\begin{array}{c}-2.09 \\
(0.25)\end{array}$ & $\begin{array}{c}-5.19^{* * *} \\
(0.00)\end{array}$ \\
1st diff & & -3.10 & $-6.72^{* * *}$ & $-5.06 * * *$ \\
ADF Stat & \multirow{2}{*}{ Yes } & $(0.13)$ & $(0.00)$ & $(0.00)$ \\
1st diff & &
\end{tabular}

$*$ significant at $10 \%$, ** significant at 5\%, *** significant at $1 \%$. P-values are in parentheses. The null hypothesis is the presence of a unit root.

Results from an ECM test for cointegration are presented in Table 12. The coefficient estimate on the error correction term is negative and statistically significant at the 5 percent level, indicating the presence of cointegration. Note that the coefficient on domestic demand is positive and statistically significant as well, which is consistent with economic theory.

Table 12. ECM Estimation Results for Imports

\begin{tabular}{|c|c|}
\hline Constant & $\begin{array}{c}0.00 \\
(0.03)\end{array}$ \\
\hline \multirow{2}{*}{ Error Correction Term } & $\begin{array}{c}\mathbf{- 0 . 5 3} * * \\
(\mathbf{0 . 2 0})\end{array}$ \\
\hline \multirow{2}{*}{ dlog(REER) } & $\begin{array}{c}0.54 \\
(0.35)\end{array}$ \\
\hline \multirow{2}{*}{ dlog(Domestic Demand) } & $\mathbf{0 . 1 2 * *}$ \\
& $\mathbf{( 0 . 0 5 )}$ \\
\hline R-squared & 0.44 \\
\hline
\end{tabular}

* significant at $10 \%, * *$ significant at 5\%, *** significant at $1 \%$. Standard errors are in parentheses. Bold numbers are statistically significant at the $5 \%$ level with expected signs. 
Results of DOLS and FMOLS estimation of the import relationship are presented in Table 13. Estimates of the import elasticity with respect to the REER are 1.15 for the DOLS model and 0.82 for the FMOLS model, with both estimates statistically significant at the 5 percent level. These estimates are close to that of 0.92 given in the IMF's EBA-lite. The estimate of import elasticity with respect to domestic demand is 0.13 and statistically significant at the 5 percent level in both specifications.

Table 13. DOLS and FMOLS Estimation Results for Imports

\begin{tabular}{|c|c|c|}
\hline Estimation Method & DOLS & FMOLS \\
\hline \multirow{2}{*}{ Constant } & -1.47 & 0.07 \\
& $(1.60)$ & $(1.41)$ \\
\hline \multirow{2}{*}{$\log ($ REER $)$} & $\mathbf{1 . 1 5}^{* * *}$ & $\mathbf{0 . 8 2} * *$ \\
$(\mathbf{0 . 3 7})$ & $(\mathbf{0 . 3 3})$ \\
\hline $\log$ (Domestic & $\mathbf{0 . 1 3} * *$ & $\mathbf{0 . 1 3} * * *$ \\
Demand) & $\mathbf{( 0 . 0 5 )}$ & $\mathbf{( 0 . 0 3 )}$ \\
\hline R-squared & 0.80 & 0.68 \\
\hline
\end{tabular}

* significant at $10 \%$, ** significant at 5\%,*** significant at $1 \%$. Standard errors are in parentheses. Bold numbers are statistically significant at the $5 \%$ level with expected signs.

\subsection{Marshall-Lerner Condition}

The Marshall-Lerner condition requires that the sum of the absolute values of export and import price elasticities exceed one. We find that even in a resource-rich economy like PNG, this condition is satisfied. Thus a depreciation of the PNG kina may be expected to result in an increase in the trade balance.

\section{COUNTER-Factual Simulation Analysis}

In the wake of the commodity price shocks of 2014, the PNG government adopted a fixed exchange rate regime with $\mathrm{FX}$ rationing. In this section, a counter-factual simulation analysis is conducted to project the consequences under an alternative flexible exchange rate policy. Based on our estimated elasticities and a calibration of our theoretical model (Equation [32]), we can calculate the impact of exchange rate adjustment on the trade balance and foreign reserves. ${ }^{6}$ Specifically, we simulate the effects of a 10 percent real effective depreciation of the kina compared to the actual exchange rate path. The 10 percent figure is chosen because currently the kina is thought to be overvalued by 10 percent. ${ }^{7}$ In practice, the REER appreciated by 2.2 percent during 2015-17 relative to 2014 . Our counter-factual analysis thus postulates depreciation of the REER by 7.8 percent (10 percent minus 2.2 percent). Note that the year 2014 was chosen as the baseline because the PNG economy was in a construction boom in 2013 due to development of a new LNG facility. To capture a more normal baseline, we chose 2014 as the

\footnotetext{
${ }^{6}$ The J-curve hypothesis holds that lagged effects of exchange rate depreciation differ from immediate effects, although empirical support for this is inconclusive (Bahmani-Oskooee and Ratha 2004). For our purposes, it does not matter since our simulated analysis uses long-run elasticities.

${ }^{7}$ See the EBA-lite REER index model in the Box 1 of IMF (2017b).
} 
benchmark year and compare activity for the following 3 years, 2015-17. The 3 year span is chosen because, as explained in the empirical section, that is the time needed for the lagged effect on agricultural production of a price change to play out. To mitigate any bias associated with a particular cointegration method, we use the average of exchange rate elasticities by DOLS and FMOLS estimators.

To carry out the simulation, parameter values must be specified for the rates of dividend payment to foreign investors made by agricultural and mining firms, $\alpha^{a}$ and $\alpha^{m}$, respectively (Equation [22]). In many developing resource-rich economies, the foreign mining companies set relatively high rates of dividend payout to secure their profits (Katz-Lavigne 2017). In other words, the mining companies keep their profits offshore and bring FX into the country only to meet payment commitments such as covering operational expenses and taxes due. This practice is similarly followed by foreign logging companies in PNG, although not generally for agriculture where offshore accounts are less common. Based on the financial statements of various mining companies, we set $\alpha^{m}=0.4$ for copper, 0.5 for gold and silver, and 1.0 for oil and logging companies, whereas for agriculture we adopt $\alpha^{a}=0$. Also, only non-resource imports are assumed to respond to exchange rate movements because resource companies rely more on their own FX held in offshore accounts making them less sensitive to exchange rate movements.

Table 14 shows the results of our simulation exercise. We find that a 10 percent real depreciation of the kina increases FX inflows via exports by $\$ 130$ million and decreases FX outflows via imports by $\$ 200$ million. On the whole, this yields an additional $\$ 330$ million in foreign reserves. Further details of this effect are displayed in Figure 8, Scenario 1, which shows a contribution from agriculture and fishery exports of $\$ 28$ million and from mining exports of $\$ 102$ million, along with the $\$ 200$ million from import reduction. 
Table 14. Counter-Factual Simulation Results: 10\% REER Depreciation of the PNG Kina

\begin{tabular}{|c|c|c|c|c|c|c|c|c|}
\hline \multirow{3}{*}{\multicolumn{2}{|c|}{\begin{tabular}{|l|} 
\\
Exports \\
\end{tabular}}} & 2014 Volume & $\begin{array}{c}\text { Average Price in } \\
2015-17\end{array}$ & $\begin{array}{l}\text { Exchange Rate } \\
\text { Elasticity }^{1}\end{array}$ & $\begin{array}{c}\text { Additional Volume } \\
\text { Change }\end{array}$ & $\begin{array}{c}\text { Additional FX } \\
\text { Change }\end{array}$ & $\begin{array}{l}\text { Foreign Shareholder } \\
\text { Ratio }^{2}\left(\alpha^{m}, \alpha^{a}\right) \\
\end{array}$ & $\begin{array}{c}\text { Actual FX } \\
\text { Inflows }\end{array}$ \\
\hline & & (a) & (b) & (c) & $(\mathrm{d})=(\mathrm{a}) \times(-0.1) \times(\mathrm{c})$ & $(\mathrm{e})=(\mathrm{d}) \times(\mathrm{b})$ & (f) & $(\mathrm{g})=(\mathrm{e}) \times(1-(\mathrm{f}))$ \\
\hline & & - & - & - & - & $\$ 190.2$ million & - & $\$ 129.9$ million \\
\hline & Gold & 58.1 tons & $\$ 39.3$ million/ton & -0.59 & 3.4 tons & $\$ 134.7$ million & 0.5 & $\$ 64.2$ million \\
\hline & Copper & 89.6 thousand tons & $\$ 5.5$ thousand/ton & -1.21 & 10.8 thousand tons & $\$ 59.8$ million & 0.4 & $\$ 38.7$ million \\
\hline & Oil & 8200 thousand tons & $\$ 48.8$ per barrel & -0.07 & 57.4 thousand tons & $\$ 2.8$ million & 1.0 & $\$ 0.0$ million \\
\hline & Silver & 53.0 tons & $\$ 0.5$ million/ton & 0.50 & -2.7 tons & \$-1.4 million & 0.5 & \$-0.7 million \\
\hline & Copra & 48.2 thousand tons & $\$ 0.6$ thousand/ton & 1.76 & -8.5 thousand tons & $\$-5.1$ million & 0.0 & $\$-5.1$ million \\
\hline & Cocoa & 33.6 thousand tons & $\$ 2.7$ thousand/ton & -0.38 & 1.3 thousand tons & $\$ 3.3$ million & 0.0 & $\$ 3.3$ million \\
\hline & Coffee & 48.4 thousand tons & $\$ 3.6$ thousand/ton & -0.62 & 3.0 thousand tons & $\$ 10.8$ million & 0.0 & $\$ 10.8$ million \\
\hline & Palm Oil & 514.8 thousand tons & $\$ 0.7$ thousand/ton & -0.05 & 2.6 thousand tons & $\$ 1.7$ million & 0.0 & $\$ 1.7$ million \\
\hline & Rubber & 3.2 thousand tons & $\$ 1.6$ thousand/ton & -0.82 & 0.3 thousand tons & $\$ 0.4$ million & 0.0 & $\$ 0.4$ million \\
\hline & Tea & 2.1 thousand tons & $\$ 1.4$ thousand/ton & -2.17 & 0.5 thousand tons & $\$ 0.6$ million & 0.0 & $\$ 0.6$ million \\
\hline & Copra Oil & 11.1 thousand tons & \$1.6/thousand/ton & -1.86 & 2.1 thousand tons & $\$ 3.3$ million & 0.0 & $\$ 3.3$ million \\
\hline & Logs & 3800 thousand cubic meters & $\$ 0.1$ thousand/ton & 0.98 & -371 thousand cubic meters & \$-33.4 million & 1.0 & $\$ 0.0$ million \\
\hline & Marine Products & 78.2 thousand tons & $\$ 1.2$ thousand/ton & -1.33 & 10.4 thousand tons & $\$ 12.7$ million & 0.0 & $\$ 12.7$ million \\
\hline & & 2014 Value & $\begin{array}{c}\text { Average Price } \\
\text { Change in 2015-17 }\end{array}$ & $\begin{array}{c}\text { Exchange Rate } \\
\text { Elasticity }^{1}\end{array}$ & Additional Value Change & $\begin{array}{c}\text { Additional FX } \\
\text { Change }\end{array}$ & $\begin{array}{c}\text { Foreign Shareholder } \\
\text { Ratio }^{3}\left(\alpha^{m} \alpha^{a}\right)\end{array}$ & $\begin{array}{c}\text { Actual FX } \\
\text { Outflows }\end{array}$ \\
\hline & & (h) & (i) & (j) & $(\mathrm{k})=(\mathrm{h}) \times(-0.1) *(\mathrm{j})$ & $(\mathrm{l})=(\mathrm{k}) \times(1+(\mathrm{i}) / 100)$ & (m) & $(\mathrm{n})=(\mathrm{l}) \times(1-(\mathrm{m}))$ \\
\hline Imports & & $\$ 4510$ million & $-27.3 \%$ & 0.98 & $\$-442.0$ million & \$-321.2 million & - & $\$-200.2$ million \\
\hline & Resource & $\$ 1700$ million & $-27.3 \%$ & 0.98 & \$-166.6 million & \$-121.0 million & 1.0 & $\$ 0.0$ million \\
\hline & Non-Resource & $\$ 2810$ million & $-27.3 \%$ & 0.98 & \$-275.4 million & \$-200.2 million & 0.0 & $\$-200.2$ million \\
\hline & & & & & & $(\mathrm{o})=(\mathrm{e})-(\mathrm{l})$ & & $(p)=(g)-(n)$ \\
\hline Net Trad & & - & - & - & - & \$511.4 million & - & $\$ 330.1$ million \\
\hline
\end{tabular}

Note 1: The average of exchange rate elasticities based on DOLS and FMOLS estimators.

Note 2: Fraction of FX inflows sent to offshore foreign currency accounts.

Note 3: Fraction of FX used to finance imports from offshore foreign currency accounts. 
Figure 8. Simulated Contributions to PNG Foreign Reserves by Source

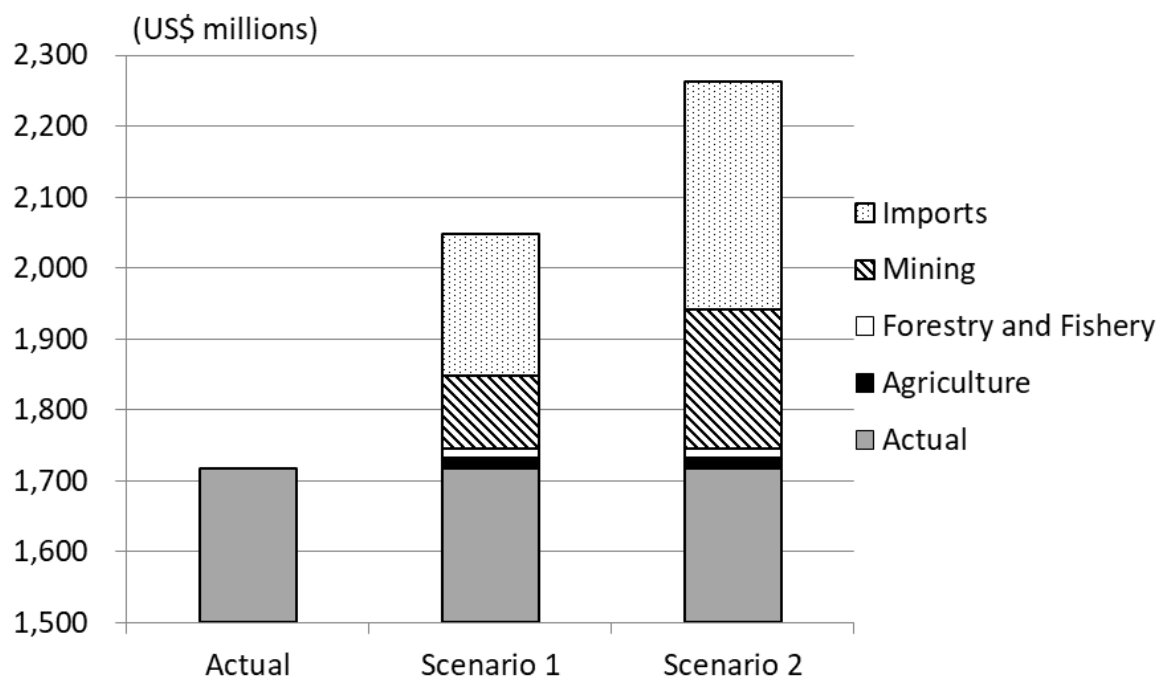

Scenario 1: 10 percent real depreciation of the kina relative to the actual exchange rate.

Scenario 2: Scenario 1 plus closure of mining companies' offshore foreign currency accounts $\left(\alpha^{m}=0\right)$.

Next, we consider a second hypothetical scenario in which the state-equity participation rate in mining projects is raised and foreign mining companies convert all their FX into domestic currency via trades with the central bank. In this case, there are no offshore accounts in mining industries. Figure 8 shows the total FX increase in Scenario 2 is $\$ 545$ million, with an additional $\$ 94$ million coming from mining exports and $\$ 121$ million from the reduction in mining companies' imports.

In summary, if, as under Scenario 1, the flexible exchange rate had been adopted in PNG after the commodity price shock of 2014 and the currency had depreciated by 7.8 percent (compared to the actual 2.2 percent appreciation), foreign reserves at the end of 2017 would have been $\$ 2,050$ million compared to the actual level of $\$ 1,718$ million. Thus Scenario 1 shows an increase in foreign reserves of 19 percent over the actual outcome. If, as under Scenario 2, this currency depreciation was accompanied by closing the offshore FX accounts of mining companies, the reserves would reach $\$ 2,263$ million at the end of 2017 . This represents an increase of 32 percent over the actual outcome.

\section{Policy Discussion}

Which is the better policy regime, FX intervention with rationing under a fixed exchange rate or a flexible exchange rate? The pros and cons of each are weighed in Table 15. Consider, for example that on the one hand, currency depreciation will increase the price competitiveness of the export sector, while on the other it will increase the debt burden denominated in foreign currency (unless the exchange rate risk is fully hedged).

Many factors weigh in favor of exchange rate flexibility. In particular, if the domestic currency depreciates as a shock absorber, profits of firms and associated tax revenues accruing to the government will increase in the domestic currency, hence balance in the fiscal budget is easier to 
maintain. Further, if the central bank wishes to sustain precautionary foreign reserves as a buffer against future external shocks, a policy requiring FX intervention poses concern. Our counter-factual simulation analysis shows that foreign reserves in PNG would have been higher by about 20 percent if the country had adopted a currency depreciation policy in response to the negative commodity price shocks. Moreover, in the event of a depreciation in the domestic currency, the government can use capital gains from its foreign reserves for fiscal financing. Further, a currency depreciation raises the domestic price of imported goods, which induces expenditure switching (Equations [14] and [15]) from foreign goods to domestic goods. Towbin and Weber (2013) found that this effect of expenditure switching is stronger for countries with a small foreign currency debt and high exchange rate pass-through, which is the case for PNG, as a flexible exchange rate regime can insulate output better from a negative terms-of-trade shock compared to a fixed regime. Thus domestic industry and the government fiscal position tend to benefit from exchange rate flexibility.

Table 15. Comparison of Two Exchange Rate Policies

\begin{tabular}{|l|c|c|}
\hline \multicolumn{1}{|c|}{ Pros (if Yes) and Cons (if No) } & $\begin{array}{c}\text { FX Rationing with Fixed } \\
\text { Exchange Rate }\end{array}$ & $\begin{array}{c}\text { Flexible Exchange } \\
\text { Rate }\end{array}$ \\
\hline 1. Import price stability as a nominal anchor & Yes & No \\
\hline 2. Exchange rate stability without overshooting & Yes & No \\
\hline 3. Minimizing opportunity cost of holding reserves & Yes & No \\
\hline 4. Management of unhedged exchange rate risk & Yes & Yes \\
\hline 5. Holding reserves as a buffer & No & Yes \\
\hline 6. Competitiveness in export sector & No & Yes \\
\hline 7. Absence of restriction on imports & No & Yes \\
\hline 8. Market-clearing price mechanism & No & Yes \\
\hline 9. Demand shift from imports to domestic goods & No & Yes \\
\hline 10. Avoiding the need for internal devaluation & No & Yes \\
\hline 11. Ease of implementation & No & Yes \\
\hline 12. Independent monetary policy & No & Yes \\
\hline 13. Less need for prudent fiscal consolidation & No & No \\
\hline 14. Averting collapse of the exchange rate regime & No & \\
\hline
\end{tabular}

An argument against allowing the PNG currency to depreciate is that this may increase import prices and result in higher inflation. To assess the costs associated with currency depreciation, we would need further analysis of exchange rate pass-through into import and domestic prices. If the country has a large share of imported goods in its consumption basket, the inflationary impetus from currency depreciation can be non-negligible. In the PNG case, the degree of pass-through may have been reduced recently due to increased competition between wholesalers and retailers. Firms have absorbed the cost associated with currency depreciation by squeezing their margins and have more aggressively sought alternative cheaper inputs from either external or domestic sources.

Ultimately, weighing of the pros and cons depends on the elasticity of exports and the relative size of foreign currency debt to exports (Nakatani 2017c). Our empirical analysis showed that for PNG both imports and commodity exports respond to real exchange rates, indicating that a depreciation of the 
currency increases exports and decreases imports. This tends to incline the policy choice in favor of exchange rate flexibility.

\section{CONCLUSION}

This study developed a theoretical model in which a negative commodity price shock causes a BOP crisis. Such a shock lowers export revenues and inflows of FX, thereby resulting in a shortage of foreign reserves. To deal with this situation, two exchange rate policies - (i) FX rationing under a fixed exchange rate and (ii) a flexible exchange rate - are compared. Our model shows that FX rationing reduces consumer welfare by creating a shadow exchange rate premium that consumers implicitly face (Figures 6 and 7). The model also suggests that a flexible exchange rate policy, which allows for a depreciation of the domestic currency, may be superior if international trade responds to the real exchange rate.

We found that export commodities in PNG - coffee, cocoa, copper, rubber, tea, etc. - have statistically significant supply elasticities with respect to the exchange rate. Our panel regression analyses show that the short-run (one-year) elasticity of exports to REER movement ranges between -0.3 and -0.7 depending on estimation methods. Cointegration regressions for each commodity support the finding of statistically significant export elasticities. ${ }^{8}$ Cointegration regressions by DOLS and FMOLS methods yield long-run elasticity estimates by commodity of between -0.5 and -2.3 , suggesting much higher responsiveness over longer time horizons. Our estimates of import elasticities also indicate responsive to the exchange rate. The upshot is that if the kina had depreciated in real effective terms following the 2014 negative commodity price shock, export volumes and hence foreign reserves would have been substantially higher than the actual level after three years. Our counter-factual simulation of the outcome under a flexible exchange rate policy showed foreign reserves being higher by 20 percent relative to the observed outcome.

Currency depreciation in response to negative commodity price shocks brings many benefits to the economy. First, as shown in our theoretical analysis, it lowers the costs of domestic currency components (such as local wages) in the balance sheets of foreign firms which are denominated in foreign currency (Equation [32]). Second, it can increase tax revenues in domestic currency as a result of higher profits of firms. Third, it may boost goods exports (as shown in our analysis), as well as potential service exports such as tourism which may be important for PNG given the country's cultural diversity, untouched wilderness, and unique wildlife. Fourth, the PNG central bank is able to preserve foreign reserves as a buffer against future external shocks. Fifth, it induces expenditure switching from imported goods to domestic goods and encourages the development of domestic industry in the medium-term. Sixth, it restores the market-clearing price mechanism and diminishes delays in meeting import orders such as arise under FX rationing, which can hinder severely normal business and government activities. Seventh, it alleviates pressures on the fiscal budget and allows a more independent monetary policy.

\footnotetext{
${ }^{8}$ Lagged effects of exchange rates on commodity exports are further analyzed with an Autoregressive Distributed Lag model in Nakatani (2017a).
} 


\section{ACKNOWLEDGEMENTS}

The author thanks two anonymous reviewers, Thomas F. Helbling, Clinton R. Shiells, Scott Roger, Chandana Kularatne, Philippe D. Karam, Paul Cashin, Vance Martin, Lucio Sarno and seminar participants at the Asia and Pacific Department Discussion Forum held at the IMF and the Staff Visit Seminar held at the BPNG for useful comments and suggestions, and Ananya Shukla for research assistance. The author also benefited from discussions with the PNG Department of Agriculture and Livestock. The views expressed here are those of the author and do not represent those of the IMF, its Executive Board, or IMF management. 
APPENDIX A

\begin{tabular}{|c|c|c|c|}
\hline Commodity Exporters & \multicolumn{3}{|c|}{ Non-Commodity Exporters } \\
\hline Algeria & Afghanistan & Greece & Panama \\
\hline Australia & Albania & Grenada & Paraguay \\
\hline Bahrain & Angola & Guatemala & Philippines \\
\hline Bolivia & Anguilla & Haiti & Poland \\
\hline Botswana & Antigua and Barbuda & Honduras & Portugal \\
\hline Brunei Darussalam & Argentina & Hungary & Romania \\
\hline Cameroon & Armenia & Iceland & Rwanda \\
\hline Canada & Aruba & India & Samoa \\
\hline Chad & Austria & Ireland & San Marino \\
\hline Chile & Azerbaijan & Israel & São Tomé and Príncipe \\
\hline Colombia & Bahamas & Italy & Serbia \\
\hline Dem. Rep. of Congo, & Bangladesh & Jamaica & Seychelles \\
\hline Republic of Congo, & Barbados & Japan & Sierra Leone \\
\hline Ecuador & Belarus & Jordan & Singapore \\
\hline Equatorial Guinea & Belgium & Kenya & Slovak Republic \\
\hline Gabon & Belize & Korea & Slovenia \\
\hline Ghana & Bhutan & Kosovo & Solomon Islands \\
\hline Guinea & Bosnia and Herzegovina & Kyrgyz Republic & South Sudan \\
\hline Guyana & Brazil & Lao & Spain \\
\hline Indonesia & Bulgaria & Latvia & Sri Lanka \\
\hline Iraq & Burundi & Lebanon & St. Kitts and Nevis \\
\hline Kazakhstan & Cabo Verde & Lesotho & St. Lucia \\
\hline Kuwait & Cambodia & Liberia & St. Vincent and Grens. \\
\hline Libya & Central African Republic & Lithuania & Swaziland \\
\hline Mauritania & China & Luxembourg & Sweden \\
\hline Mexico & Comoros & Macedonia & Switzerland \\
\hline Mongolia & Costa Rica & Madagascar & Tajikistan \\
\hline Mozambique & Croatia & Malawi & Tanzania \\
\hline Nigeria & Cyprus & Malaysia & Thailand \\
\hline Norway & Czech Republic & Maldives & Tonga \\
\hline Oman & Denmark & Malta & Tunisia \\
\hline Papua New Guinea & Djibouti & Mauritius & Turkey \\
\hline Peru & Dominica & Micronesia & Uganda \\
\hline Qatar & Dominican Republic & Moldova & Ukraine \\
\hline Russian Federation & Egypt & Montenegro & United Kingdom \\
\hline Saudi Arabia & El Salvador & Montserrat & United States \\
\hline South Africa & Estonia & Morocco & Uruguay \\
\hline Sudan & Ethiopia & Myanmar & Vanuatu \\
\hline Suriname & Fiji & Namibia & Vietnam \\
\hline Timor-Leste & Finland & Nepal & West Bank and Gaza \\
\hline Trinidad and Tobago & France & Netherlands & Zimbabwe \\
\hline United Arab Emirates & Gambia & New Zealand & \\
\hline Venezuela & Georgia & Nicaragua & \\
\hline Zambia & Germany & Pakistan & \\
\hline
\end{tabular}




\section{APPENDIX B}

Under the case of a fixed exchange rate with FX rationing, the household optimization problem results in a corner solution of $Y_{2}^{i}=Y_{2}^{i, \text { Ration }}$. We demonstrate this for the case of a household utility function with constant elasticity of substitution. The utility function is given as:

$$
U\left(L_{t}^{a}, L_{t}^{m}, Y_{t}^{a, d}, Y_{t}^{m, d}, Y_{t}^{i}\right)=\frac{C_{t}^{1-\sigma}}{1-\sigma}+\aleph \frac{\left(1-L_{t}^{a}-L_{t}^{m}\right)^{1-\gamma}}{1-\gamma}
$$

where $\sigma>0$ and $\gamma>0$, with total consumption then defined as: ${ }^{9}$

$$
C_{t}=\left\{\left(Y_{t}^{a, d}\right)^{\rho}+\left(Y_{t}^{m, d}\right)^{\rho}+\left(Y_{t}^{i}\right)^{\rho}\right\}^{\frac{1}{\rho}}
$$

where $-\infty<\rho<1, \rho \neq 0$ and $\frac{1}{1-\rho}$ is the elasticity of substitutions among consumption goods. The first order conditions of the household optimization problem, based on Equations (14) to (18), are written as:

$$
\begin{gathered}
\left(Y_{t}^{a, d} / Y_{t}^{i}\right)^{\rho-1}=P_{t}^{a, d} /\left(P_{t}^{i} E_{t}\right) \\
\left(Y_{t}^{m, d} / Y_{t}^{i}\right)^{\rho-1}=P_{t}^{m} / P_{t}^{i} \\
\aleph\left(1-L_{t}^{a}-L_{t}^{m}\right)^{-\gamma} /\left\{C_{t}^{-\sigma}\left(Y_{t}^{a, d}\right)^{\rho-1}\right\}=W_{t}^{a} / P_{t}^{a, d}, \\
\aleph\left(1-L_{t}^{a}-L_{t}^{m}\right)^{-\gamma} /\left\{C_{t}^{-\sigma}\left(Y_{t}^{m, d}\right)^{\rho-1}\right\}=W_{t}^{m} /\left(P_{t}^{m} E_{t}\right), \\
\beta C_{t+1}{ }^{-\sigma}\left(Y_{t+1}^{a, d}\right)^{\rho-1}\left(1+i_{t}-\delta\right) P_{t}^{a, d}=C_{t}^{-\sigma}\left(Y_{t}^{a, d}\right)^{\rho-1} P_{t+1}^{a, d} .
\end{gathered}
$$

If the government chooses FX rationing in response to the BOP crisis caused by the negative export price shocks, i.e., $Y_{2}^{i}=Y_{2}^{i, \text { Ration }}$, then the first order conditions above yield the following domestic demand equations for agricultural and mining goods, respectively:

$$
\begin{gathered}
Y_{2}^{a, d}=\left(\frac{P_{2}^{a, d}}{P_{2}^{i} E_{2}}\right)^{\frac{1}{\rho-1}} Y_{2}^{i, \text { Ration }}, \\
Y_{2}^{m, d}=\left(\frac{P_{2}^{m}}{P_{2}^{i}}\right)^{\frac{1}{\rho-1}} Y_{2}^{i, \text { Ration }} .
\end{gathered}
$$

\footnotetext{
${ }^{9}$ Note that $\sigma=\gamma=1$ corresponds to the case of more restrictive Cobb-Douglas utility function. A CES function is chosen in preference to a Cobb-Douglas function so as to illustrate the role of substitutability in policy discussion.
} 


\section{REFERENCES}

Aba, L. A., Aipi, B., \& Irau, T. (2012a). Supply response of coffee in Papua New Guinea. Bank of Papua New Guinea Working Paper 2012/01.

Aba, L. A., Aipi, B., \& Irau, T. (2012b). Supply response of cocoa in Papua New Guinea. Bank of Papua New Guinea Working Paper 2012/02.

Aba, L. A., Aipi, B., \& Irau, T. (2012c). Supply response of palm oil in Papua New Guinea. Bank of Papua New Guinea Working Paper 2012/03.

Adler, G, Magud, N. E., \& Werner, A. (2018). Terms-of-trade cycles and external adjustment. International Review of Economics and Finance, 54, 103-122.

Bahmani-Oskooee, M., \& Ratha, A. (2004). The J-curve: A literature review. Applied Economics, 36, 1377-1398.

Behar, A., \& Fouejieu, A. (2016). External adjustment in oil exporters: The role of fiscal policy and the exchange rate. IMF Working Paper 16/107.

Broda, C. (2004). Terms of trade and exchange rate regimes in developing countries. Journal of International Economics, 63, 31-58.

Burnside, C., Eichenbaum, M., \& Rebelo, S. (2004). Government guarantees and self-fulfilling speculative attacks. Journal of Economic Theory, 119, 31-63.

Caballero, R. J., \& Krishnamurthy, A. (2001). International and domestic collateral constraints in a model of emerging market crises. Journal of Monetary Economics, 48, 513-548.

Cashin, P., Mohaddes, K., \& Raissi, M. (2017). Fair weather or foul? The macroeconomic effects of El Niño. Journal of International Economics, 106, 37-54.

Céspedes, L. F., \& Velasco, A. (2012). Macroeconomic performance during commodity price booms and busts. IMF Economic Review, 60, 570-599.

Chang, R., \& Velasco, A. (2001). A model of financial crises in emerging markets. Quarterly Journal of Economics, 116, 489-517.

Driscoll, J. C., \& Kraay, A. C. (1998). Consistent covariance matrix estimation with spatially dependent panel data. Review of Economics and Statistics, 80, 549-560.

Edwards, S., \& Levy Yeyati, E. (2005). Flexible exchange rate as shock absorbers. European Economic Review, 49, 2079-2105.

IMF. (2015). Exchange rates and trade flows: Disconnected? In World economic outlook. Adjusting to lower commodity prices (pp. 105-142). Washington, DC: IMF.

IMF. (2016). Methodological note on EBA-lite. IMF Policy Paper, February 8. 
IMF. (2017a). External adjustment to terms-of-trade shifts. In Regional economic outlook. Western hemisphere: Tale of two adjustments (pp. 55-79). Washington, DC: IMF.

IMF. (2017b). Papua New Guinea: Staff report. IMF Country Report No.17/411.

Kao, C. (1999). Spurious regression and residual-based tests for cointegration in panel data. Journal of Econometrics, 90, 1-44.

Katz-Lavigne, S. G. (2017). The renegotiation window: Resource contract renegotiation in the mining industry in Africa from 2000 to 2013. Resources Policy, 51, 22-30.

Krugman, P. (1979). A model of balance-of-payments crises. Journal of Money, Credit and Banking, 11, 311-325.

McKinnon, R. I., \& Pill, H. (1999). Exchange-rate regimes for emerging markets: Moral hazard and international overborrowing. Oxford Review of Economic Policy, 15, 19-38.

Nakatani, R. (2014). The effects of financial and real shocks, structural vulnerability and monetary policy on exchange rates from the perspective of currency crises models. UTokyo Price Project Working Paper Series No.061, Graduate School of Economics, University of Tokyo. http://www.price.e.u-tokyo.ac.jp/img/researchdata/pdf/p wp061.pdf

Nakatani, R. (2016). Twin banking and currency crises and monetary policy. Open Economies Review, 27, 747-767.

Nakatani, R. (2017a). External adjustment in a resource-rich economy: The case of Papua New Guinea. IMF Working Paper 17/267.

Nakatani, R. (2017b). The effects of productivity shocks, financial shocks and monetary policy on exchange rates: An application of the currency crisis model and implications for emerging market crises. Emerging Markets Finance and Trade, 53, 2545-2561.

Nakatani, R. (2017c). Structural vulnerability and resilience to currency crisis: Foreign currency debt versus export. The North American Journal of Economics and Finance, 42, 132-143.

Nakatani, R. (2018a). Real and financial shocks, exchange rate regimes and the probability of a currency crisis. Journal of Policy Modeling, 40, 60-73.

Nakatani, R. (2018b). Output costs of currency crisis and banking crisis: Shocks, policies and cycles. Comparative Economic Studies, forthcoming. https://doi.org/10.1057/s41294-018-0069-1

Nakatani, R. (2018c). Output costs of currency crises: Shocks, policies and cycles. MPRA Paper 83549.

Nkang, M. N., Abang, S. O., Akpan, O. E., \& Offem, K. J. (2006). Co-integration and error-correction modelling of agricultural export trade in Nigeria: The case of cocoa. Journal of Agriculture and Social Sciences, 2, 249-255. 
Obstfeld, M. (1996). Models of currency crises with self-fulfilling features. European Economic Review, 40, 1037-1047.

Pedroni, P. (1999). Critical values for cointegration tests in heterogeneous panels with multiple regressors. Oxford Bulletin of Economics and Statistics, 61, 653-670.

Pedroni, P. (2000). Fully modified OLS for heterogeneous cointegrated panels. Advances in Econometrics, 15, 93-130.

Phillips, P. C. B., \& Hansen, B. E. (1990). Statistical inference in instrumental variables regression with I(1) processes. Review of Economic Studies, 57, 99-125.

Stock, J. H., \& Watson, M. W. (1993). A simple estimator of cointegrating vectors in higher order integrated systems. Econometrica, 61, 783-820.

Towbin, P., \& Weber, S. (2013). Limits of floating exchange rates: The role of foreign currency debt and import structure. Journal of Development Economics, 101, 179-194.

van Wijnbergen, S. (1991). Fiscal deficits, exchange rate crises and inflation. Review of Economic Studies, 58, 81-92. 